\title{
Structural Control of
}

\section{Uranium-Bearing Vein}

Deposits and Districts

in the Conterminous

United States

GEOLOGICAL SURVEY PROFESSIONAL PAPER 455-G

Prepared on behalf of the

U.S. Atomic Energy Commission

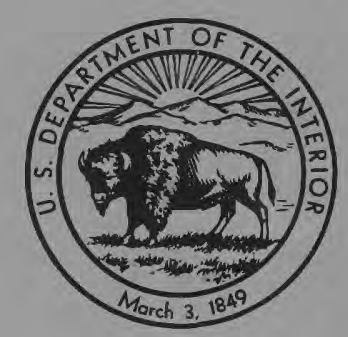




\section{Structural Control of}

Uranium-Bearing Vein

Deposits and Districts

in the Conterminous

United States

By FRANK W. OSTERWALD

GEOLOGY OF URANIUM-BEARING VEINS IN THE CONTERMINOUS UNITED STATES

GEOLOGICAL SURVEY PROFESSIONAL PAPER 455-G

Prepared on behalf of the

U.S. Atomic Energy Commission

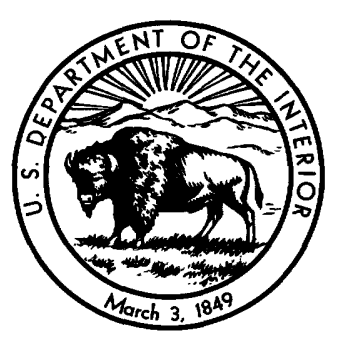

UNITED STATES GOVERNMENT PRINTING OFFICE, WASHINGTON : 1965 
UNITED STATES DEPARTMENT OF THE INTERIOR

STEWART L. UDALL, Secretary

GEOLOGICAL SURVEY

Thomas B. Nolan, Director

For sale by the Superintendent of Documents, U.S. Government Printing Office

Washington, D.C. 20402 - Price 30 cents (paper cover) 


\section{CONTENTS}

Abstract.

Introduction . .

Shape of uranium-bearing veins_..._.

Internal structure of ore shoots within veins _.. 123

Structural control of deposits. 123

Fractures and fracture zones_._._. 123

Fractures cutting favorable host rocks_...
Page

Structural environment of uranium districts........... 134 Districts adjacent to large-scale structural features_. $\quad 136$

Districts in crystalline-rock masses. ........... 140

Districts with linked tension fractures between large-scale faults or shear zones................. 141

Summary

Literature cited......... 144

\section{ILLUSTRATIONS}

FIGURE 44. Sketch showing structural characteristics of pitchblende-bearing veinlets between footwall and hanging wall seams, Carroll mine 45-46. Photographs of-

45. Brecciated fault contact between steeply dipping Paleozoic(?) limestone and granitic rocks of Cretaceous(?) age, at Hoping No. 1 incline

46. Tabular breccia zone containing uranium minerals in Madison Limestone of Mississippian age, Fuesner mine . . . . .

47. Cross section through Crooks Gap area, Fremont County, Wyo 48-52. Photographs of-

48. Uranium ore body in fractured Tertiary(?) conglomerate and sandstone, Mary L claim .

49. View west along length of stoped-out ore roll showing fault along north side of roll, Rex No. 1 mine $\ldots$

50. Fault in back of stoped-out ore roll, Rex No. 1 mine

51. Uranium ore, about $1 \frac{1}{2}$ feet wide, in fault at east end of ore roll, Rex No. 1 mine

52. View east of uranium ore body within permeable rocks of Eocene age in uplifted fault block at RanRex mine

53. Geologic map of part of the Ridenour mine showing uraniferous copper vein and outline of mine workings

54. Sketch map showing location of Ridenour mine with respect to Hurricane and Toroweap faults...

55. Photograph of east face of opencut at Hack Canyon mine showing fault in sedimentary rocks of Paleozoic age

56. Sketch map showing location of Ralston Creek and Golden Gate Canyon districts with respect to intermediatescale faults and fault zones.

57. Cross section through Golden Gate fault, near Morrison, Colo 58-61. Sketch maps showing-

58. Structural pattern of Gas Hills district.

59. Structural pattern of Maybell-Lay district

60. Marysvale district, Piute County, Utah, showing relation of mine area to regional structure

61. Traces of major veins in part of the Freeland-Lamartine district. 


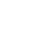




\title{
GEOLOGY OF URANIUM-BEARING VEINS IN THE CONTERMINOUS UNITED STATES
}

\section{STRUCTURAL GONTROL OF URANIUM-BEARING VEIN DEPOSITS AND DISTRICTS IN THE CONTERMINOUS UNITED STATES}

\author{
By Frank W. Osterwald
}

\begin{abstract}
Uranium-bearing veins in the United States are principally fissure-filling deposits in faults, joints, or fracture zones that have resulted from compressive, tensile, or torsional stresses. The individual ore bodies within vein deposits are tabular sheetlike masses or ore shoots along veins, irregular stockworks along fault zones, or pipelike masses either in fault intersections or in blocks of broken ground. Many veins consist of gouge or breceia containing uranium minerals. Rocks adjacent to faults, joints, or fault zones may also contain uranium if they are porous or reactive, or if they are broken.

Most uranium-bearing vein districts in the United States are in structural environments in which subsidiary intermediateto small-scale faults and folds are related spatially to largeto intermediate-scale folds, anticlinal uplifts, crystalline-rock masses, or faults. Deposition of uranium commonly occurs late in the structural history of a district.
\end{abstract}

\section{INTRODUCTION}

This report is one of a series on the geology of uranium-bearing veins in the conterminous United States and is based on work done on behalf of the U.S. Atomic Energy Commission. Six other reports have been published (1963) as chapters of Professional Paper 455, Geology of uranium-bearing veins in the conterminous United States. (See "Volume Contents.") The scope of the series of reports was described by Walker and Osterwald (1963, p. 2) as follows:

Reviews of available reports and compilation of data for this report were started in the late autumn of 1953 and continued, with many interruptions, until June 1957. In general, data from reports that became available after June 1957 were not included in this paper, but this cutoff date was not rigorously observed. The authors have tried to review all reports that have a direct bearing on the geology of the uraniferous veins in the United States, but some sources of information undoubtedly have been overlooked; others, though reviewed, have been intentionally omitted. Some reports are not referred to because (a) they are known to be inaccurate or incomplete, (b) different data within a given source report are grossly confiicting, or (c) other reports present the same data in greater detail. Most geologic reports reviewed resulted either directly or indirectly from the Federal Government's program on raw materials for atomic energy. The basic philosophy behind the program changed from one largely restricted to ore finding and prospecting to one directed toward fundamental studies of geologic distribution, uranium mineralogy and geochemistry, and geophysical principles related to uranium.
This transition in the program from one of immediate economic, military, and political importance to one of scientific interest took place principally in the years 1953-55, during which time this report was planned and partly written.

The present chapter deals primarily with the structural controls for uranium-bearing vein deposits and districts. The available information pertaining to the structure of uranium-bearing veins was reviewed and the patterns of the structural features associated with the veins were studied to learn if they might provide any guidance to the locations of uranium districts before prospecting and exploration.

The structural control of uranium-bearing veins is commonly a fracture (fault or joint) or a group of fractures. In places, however, the control is the intersection of these structural features with folds or with porous or reactive wallrocks. The position of some veins is determined by open spaces along rock contacts. Groups of these controlling structural features commonly are spatially related to larger structural features, such as uplifts and igneous intrusive masses, and form uranium districts when mineralized.

The structure of each known uranium-bearing vein has not been described in detail here. Many details have been considered, however, to form generalizations concerning the structures and structural environments favorable for such deposits. These generalizations are not sufficiently definitive to be applicable everywhere because of a general lack of pertinent information. The reasons for this inadequacy are the same as those stated by Newhouse $(1942$, p. 23$)$ to explain inadequate information about the subsidiary structural features associated with faults and their relation to ore deposits in general:

* * * In view of their major economic importance it is surprising how scanty is the factual information on the various interrelations mentioned between these subsidiary features and the major or larger faults with which they are associated. Geologists only too frequently state that the ore deposits are in the faults or fissures subsidiary to the larger faults and fail to describe or illustrate the facts of spatial and time relationships. The following discussion is quite inadequate to the needs of a subject which is considered to be one of the most important 
and one of the least described types of structural features with which ore is associated.

The need for more accurate and complete description is most acute at those localities where an obvious feature, such as a major fault or a rock with suitable openings, is intersected by a subtle feature, such as a belt of small closely spaced fractures or a minor fold. Because of the disparity in accuracy and detail of the structural data from various places, the author has weighted heavily the information from a few well-known districts and supplemented this with fragmentary information from less well known mines and prospects.

\section{SHAPE OF URANIUM-BEARING VEINS}

The shape of uranium-bearing veins, as that of other ore deposits, depend upon (1) primary openings in the host rock, $(2)$ secondary openings made by mechanical deformation of the rock, and (3) secondary openings made by chemical solution of the host. The shape of openings made by mechanical deformation is most important of the three types; these openings are the result of both the shape of fractures and the amount and direction of movement along them.

Many uranium-bearing veins are tabular sheetlike lenticular bodies controlled by simple fractures, whereas other uranium-bearing veins are sinuous, in both plan and section. Irregular stockworks, or ladder veins, occur in some fracture zones, and pipelike structural features having a variety of shapes occur at fracture intersections and in breccia pipes.

The veins along single faults, such as many of those in the Front Range, in the Marysvale district, Utah, and in other districts of the western United States, are tabular bodies of fairly uniform thickness although they change in thickness both laterally and vertically, coincident with changes in dip and strike of the controlling faults. Many of the uranium-bearing veins in the Front Range are in single open fractures or in local openings along single fractures (Sims, 1956, p. 751, 755). The uranium minerals within these deposits occur irregularly "in ore shoots or smaller lenses, pods, and stringers that are separated by vein filling that is essentially devoid of uranium" (Sims, 1956, p. 751). Where faults split and rejoin or where two faults intersect, a cylindrical ore body may develop.

The pitchblende veinlet in a late fracture along the footwall of the Wood vein in the East Calhoun mine, Central City district, Gilpin County, Colo., apparently is in a thickened part of the vein that was localized by a change in strike, and perhaps a change in dip, of the fault structure (Drake, 1957, pls. 13, 14, 15). The fractures that controlled the metalliferous ore shoots within the veins of the Central City district generally are less distinct than the fracture system that controlled the deposition of small pitchblende masses. The plunge of many of the gold ore shoots in the Central City district is parallel to the plunge of the intersection of the veins with rock layering (Collins, 1930, p. 260-261). Most of the base-metal ore shoots in the district are either at these intersections or at intersections of two veins (Sims, 1956, p. 756). Many of the pitchblende "ore shoots" probably are controlled by similar features.

Irregular stockworks are most common in granitoid rocks; some of the deposits at Marysvale, Piute County, Utah, are perhaps the best examples in the United States of this type of uraniferous deposit (Kerr and others, 1957 , p. 144-145, 147-148; Walker and Osterwald, 1956, p. 125). Well-defined ore shoots are contained in the pitchblende-bearing veins at Marysvale, Utah, particularly in the Prospector mine workings in quartz monzonite (Kerr and others, 1957, p. 145). The uranium-bearing material in most of the veins at Marysvale pinches and swells, and some of the richest ore occurs in shoots at intersections of faults belonging to different fault sets or at places where the strike of the vein changes (Walker and Osterwald, 1956, p. 125). Mineralization in the No. 1 vein of the Freedom No. 2 mine was more intense where the dip was steep than it was where the dip was less steep (Kerr and others, 1957, p. 148). Some of the veins at Marysvale are linked by minute gash fractures to veinlets that parallel the vein walls (Kerr and others, 1957, p. 144-145).

These ladderlike veins are most common in shear zones that cut rocks of varied hardness. Some of the best examples of the ladderlike veins are in the Avery County, N.C., uranium deposits where pitchblende veins cut granitic pegmatite dikes at high angles to shear fractures in the country rock. The shear fractures parallel the contacts of the dikes with the enclosing schists.

The shape of some uranium deposits is determined by the intersection of subsidiary and major faults or fractures. Such deposits may be circular in plan, such as that at the Orphan Lode, Grand Canyon National Park, Ariz., or they may be $Y$-shaped in plan, such as that at the Los Ochos mine, near Gunnison, Colo. Part of the uranium deposit at the Los Ochos mine is an ore shoot formed within a block of broken rock near two intersecting faults (Derzay, 1956). The ore shoot is localized in brecciated Morrison Formation of Jurassic age and in underlying Precambrian rocks where a major high-angle reverse fault having 4 to 12 inches of gouge intersects a second fault and its parallel subsidiary fractures. 


\section{INTERNAL STRUCTURE OF ORE SHOOTS WITHIN VEINS}

Veins containing uranium, as might be expected, are commonly deformed during the introduction of gangue and ore minerals. The result is a series of small-scale fractures or a breccia that could localize any late uranium minerals.

The pitchblende in the veins of the Central City district, Colorado, occurs as small pods, lenses, veinlets, and irregular masses grouped within larger features termed "ore shoots" (Sims, 1956, p. 751-755; Drake, 1957, p. 164-166; Moore and Butler, 1952). These ore shoots are simply the parts of the veins that contain pitchblende; those in the Wood vein were described by Drake (1957, p. 166). Within these ore shoots small masses of pitchblende are localized by small faults or joints within and adjacent to the veins, most commonly along or near the footwalls. Small scale control of pitchblende veinlets has been noted also on the 228-foot level west, Carroll mine, Colorado (Sims, 1956, p. 754). The two principal veinlets, as shown in figure 44, are near the hanging wall of the vein and are linked by minute gash fractures containing pitchblende; the hanging-wall veinlet is thickened at its intersection with some of the gash fractures.

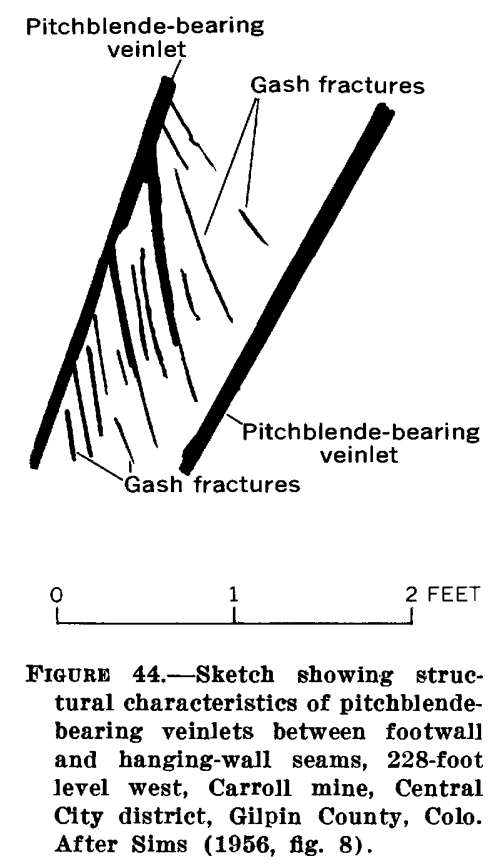

\section{STRUCTURAL CONTROL OF DEPOSITS}

The structural control of individual deposits is caused by deformation that either creates openings accessible to solutions or forms impervious dams and semipermeable barriers. These openings and barriers may be along a single fault or joint, along a fault zone, or in irregular masses of broken, permeable, or reactive rock near one of these structural features. Such structural settings are transitional with one another; commonly two or more settings characterize a deposit. The structural controls that characterize many veins in faulted and fractured clastic sedimentary or pyroclastic rocks grade into the subtle stratigraphic controls that characterize disseminated and replacement (sandstone-type) uranium deposits. The various kinds of openings, as well as the dams and barriers, are described as related to uranium-bearing veins in the conterminous United States; some deposits that are transitional to sandstone types are described briefly to illustrate less obvious structural controls.

\section{FRACTURES AND FRACTURE ZONES}

In general, uranium and other minerals in vein deposits fill open spaces along either a single fracture (fault or joint) or a group of fractures; if the fractures are straight and smooth, they may be evenly mineralized, but, if they are irregular, ore shoots form in the open parts of the fracture. Differential movement along irregular fractures commonly breaks rock in and adjacent to these fractures. The nature of the broken masses depends upon the physical properties of the rocks; brittle competent rocks commonly form a loosely consolidated porous breccia, whereas soft incompetent rocks such as shale or schist form impermeable gouge (T. S. Lovering, 1942, p. 7). The type of brecciated rock, however, depends also upon the intensity of deformation; a slightly deformed incompetent rock may form an unconsolidated breccia, but a similar rock if strongly deformed may form gouge. Both types of broken rock seem to have affected the localization of uranium-bearing veins.

Uranium deposits in some fracture zones consist of many minute veinlets containing pitchblende and other minerals. In other fault zones, gouge or uranium-bearing mylonite contain abundant uranium minerals. Some deposits consist of fault breccia partly cemented by uranium minerals or of zones of closely spaced joints intersecting permeable or reactive rock.

Many uranium-bearing vein deposits consist of 6 valent or 4-valent uranium minerals and gangue which fill fractures in breccia, gouge, or mylonite, or fill intersections of faults with other structural features. Porous rock adjacent to breccia zones may also contain uranium minerals. Many such deposits are transitional between veins filling single fractures and disseminated and replacement deposits in porous sedimentary rocks (sandstone-type deposits). Examples of these various favorable structural environments are presented to show the complex and interrelated character of the deposits associated with them. Only the most obvious structural 
control is described for most of the deposits. Other unrecognized and more subtle controls may be as important or more important than the one described, but information to evaluate these subtle controls is not available.

Intersecting fractures or fracture zones seem to have localized some uranium-bearing veins in the United States as well as many deposits of other minerals ( Hulin, 1929, p. 41-44). Some of the uranium-bearing veins at Marysvale, Piute County, Utah, are enlarged slightly at intersections of the different fault sets, and as a result some ore is in pronounced shoots (Kerr and others, 1957, p. 58, fig. 81; Walker and Osterwald, 1956, p. 124-125). In the Martha $\mathrm{E}$ mine, Clear Creek County, Colo., hexavalent and tetravalent uranium minerals occurred near the intersections of a vein with minor faults, joints, intersecting veins, and splits (Harrison, 1953, p. 96). Most of the uranium ore shoots associated with the copper and tin ores of Cornwall, England, were formed at "cross-courses" (Ussher, Barrow, and MacAlister, 1909, p. 155-156), which were probably cross faults.

The largest pitchblende ore shoot in the Caribou mine, Boulder County, Colo., was along a curving easttrending fault subsidiary to the main silver ore vein (L. R. Page, written commun., 1959). A pitchblende veinlet followed the footwall of the main fault, curved, and then followed the subsidiary fault (Moore and others, 1957, pl. 37; Ridland, 1950). Similar structural controls are well illustrated by the deposits at St. Joachimsthal (Jachymov), in central Europe, where uranium is localized at the intersections of east-trending veins with north-trending veins (Kraus, 1915). The ore bodies, however, are further localized within the less steep parts of the veins, which follow normal faults, and at intersections of the veins with favorable metamorphic rocks.

Both primary and secondary fractures within igneous intrusives contain localized uranium-bearing veins in some places. Uranium-bearing vein deposits occupying primary fractures within igneous intrusives are not common in the United States but are common in Europe. The Werra mine, Bavaria, for example, contains hexavalent uranium minerals along tension fractures at right angles to schlieren within a granitic stock of Carboniferous age (D. L. Everhart, written commun., 1952). The 6-valent uranium minerals, however, are near the contact of the stock with gneiss of Precambrian age and occur only in scattered parts of the mine. Elsewhere in the mine, the schlieren contain sulfide and uraniumbearing minerals. In the United States, at the Miracle and Kergon mines, Kern County, Calif., 4-valent and 6 -valent uranium minerals coat fracture surfaces and are disseminated in gouge along shear zones that are part of a regional joint and fault pattern. Although the joints and faults are nearly parallel to flow structures within the intrusive, the joints and faults were unrelated to the flow structures, according to E. M. MacKevett, Jr. (written commun., 1958). At the Daybreak mine, Washington, 6-valent uranium minerals are in and near an east-trending fault zone in the Loon Lake batholith (Weis, 1956, p. 223). The information available is not sufficient to determine whether this fault zone is part of a regional fracture pattern or of a pattern of flow structures only in the batholith.

Some uranium-bearing veins in the United States are associated with contacts between metamorphic and granitic rocks that are cut by faults or fault zones; examples of such occurrences are at the Midnite mine, Stevens County, Wash., and the Early Day mine, Lander County, Nev. (Thurlow, 1956). The relation between the uranium deposits and contacts in many such deposits is one in which the contact itself serves as a favorable structure and not necessarily as a boundary between rocks that differ in their reactive characteristics with ore solutions. These deposits, therefore, are not of contact-metamorphic origin. Many of the contacts are faults themselves. Although the uranium in such deposits is commonly more abundant in the metamorphic rocks than in the intrusive rocks, this distribution probably is attributed to physical conditions near the contact, rather than to control by chemical reactions. Breaking properties of the rock, perhaps affected by silicification or by other changes resulting from intrusion, metamorphism, and faulting of the contacts, probably control distribution of openings that localize deposits near the contacts.

The Midnite mine is along the contact between altered metamorphic rock and intrusive quartz monzonite (Becraft and Weis, 1957; written commun., 1958). Veins containing 4-valent uranium minerals and pyrite cut the metamorphic rock but not the quartz monzonite beneath an oxidized zone (Becraft and Weis, written commun., 1958). Most of the uranium is in faulted zones (Becraft, 1956a, p. 148) that intersect the contact between metasedimentary rock and the quartz monzonite at an oblique angle.

The uranium-bearing veins at the Early Day mine are in faults and fracture zones near a contact between metasedimentary rock and granitic rock; most of the uranium is within the metasedimentary rock. A small amount of uranium is disseminated in small roof pendants in granitic rock near the contact.

Some deposits consist almost entirely of fault breccia cemented by uranium minerals and other introduced minerals. An excellent example is the Hoping No. 1 
claim, San Bernardino County, Calif., where limestone of Paleozoic(?) age is in fault contact with granitic rock of Cretaceous( ?) age. A fault breccia, averaging 3 feet in thickness, is cemented by purple fluorite, gypsum, and yellow 6-valent uranium minerals (fig. 45). Some of the masses of ore in the breccia are irregular; they were deposited along bedding planes and joints extending into limestone blocks and along subsidiary faults in limestone country rock.

Some deposits in the Pryor Mountains, Carbon County, Mont., and Little Mountain district, Big Horn County, Wyo., are structurally similar to mineralized fault gouge and breccia (fig. 46). These deposits consist of cave fillings both of fine-grained debris and of coarse collapse breccia impregnated with uranium minerals and with lesser amounts of pyrite, fluorite, and asphaltite (Hauptman, 1956; Armstrong, 1957, p. 217). The caves in the Little Mountain district are alined with regional joints and faults, which probably controlled the solution of limestone (K. G. Bell, oral commun., 1956). In addition, regional tilting and minor movement on joints and faults probably occurred after formation of the caves.

The uranium deposit at the Hazel mine, Fremont County, Wyo., represents low-temperature mineralization of gouge. This deposit consists of abundant hexavalent uranium minerals in dark-colored gouge along a high-angle reverse fault (Stephens, 1964, p. F48-F49) between nonresistant Cody Shale of Cretaceous age and undivided sedimentary rocks of Triassic age (fig. 47). The gouge contains pyrite, schroeckingerite, and perhaps other uranium minerals (T. L. Finnell, oral commun., 1956). The uranium deposit at the Surprise No. 1 claim, Kern County, Calif., is structurally similar to that at the Hazel mine although it has more coarsely divided rock debris in the fault. Uranium at the Surprise No. 1 is dispersed in a nearly vertical zone of broken rock about 60 feet wide. The zone, which cuts the McLure Shale Member of the Monterey Shale of Miocene age, contains breccia, gouge, and some siliceous boxwork and is cemented with gypsum, calcium carbonate minerals (some of which are radioactive), and a small amount of fluorite.

An unusual type of breccia deposit at the Ontario Minerals property, Inyo County, Calif., a uraniumbearing mylonite, was described briefly by A. C. Waters (written commun., 1956). The mylonite, called pseudotachylite by Waters, contains small amounts of sulfide minerals and uranium along a nearly vertical fault zone 3 to 4 feet thick in Cretaceous(?) quartz monzonite. Fractures extending outward from the main fault zone also contain mylonite and curve upward into the gently dipping foliation of the quartz monzonite. The eastern margin of the fault zone is bordered by a body of fragmented rock that resembles a pebble dike. According to A. C. Waters (written commun., 1956), the deposit probably formed from hot gases that passed through the fault zone, and it represents uranium mineralization of finely comminuted rock debris at high temperature.

Some deposits consist both of mineralized fault gouge and breccia and of disseminated uranium in porous wallrock. An example is the Rajah mine, Montrose County, Colo., where some of the ore was in thin veinlets, lenses, and pods in fault gouge and breccia (Shoemaker, 1956, p. 165-166), but where apparently, most of the uranium was disseminated in sedimentary rocks of Jurassic age in the footwall of a fault zone. According to a cross section by Shoemaker (1956, fig. 28), much ore was localized on the steeper parts of the fault.

Broken rock (breccia) adjacent to a fault apparently controlled the deposition of some uranium ore at the Mary L claim, Tallahassee Creek district, Fremont County, Colo. (fig. 48). At this claim, conglomerate and sandstone of Tertiary(?) age are broken into small blocks, most of which are less than 1 foot in greatest dimension. The broken rock is beneath a high-angle reverse fault; the hanging wall for the fault and for the ore deposit consists of rocks of Precambrian age.

The Good property near Gorman, Los Angeles County, Calif., is another example of uranium deposition controlled by fractured rock adjacent to a fault. At this property, sedimentary rocks of Pliocene(?) age are strongly folded and faulted in the footwall of a steeply dipping reverse fault. Scattered chunks of highly radioactive coal as much as 6 inches in diameter are in the fault rubble. The broken rock adjacent to the fault was mineralized, apparently, because fault gouge impeded further movement of solutions, and because the blocks in the fault rubble presented a large surface area to permeative or reactive solutions.

Sets of closely spaced joints can also aid in localizing deposits that are transitional to sandstone-type deposits. An example is the Cedar Canyon deposit, Harding County, S. Dak., in which hexavalent uranium minerals are concentrated along joints and disseminated in finegrained tuffaceous sandstone and sandy claystone of the Chadron Formation of Oligocene age (Gill and Moore, 1955, p. 256-257). A zone of closely spaced joints, parallel to one of the regional joint sets, passes through the Cedar Canyon deposit. Similar closely spaced joint sets are also associated with some uranium deposits in permeable sandstone and reactive limestone beds at Grants, N. Mex. (Thaden, 1955, p. 59). 


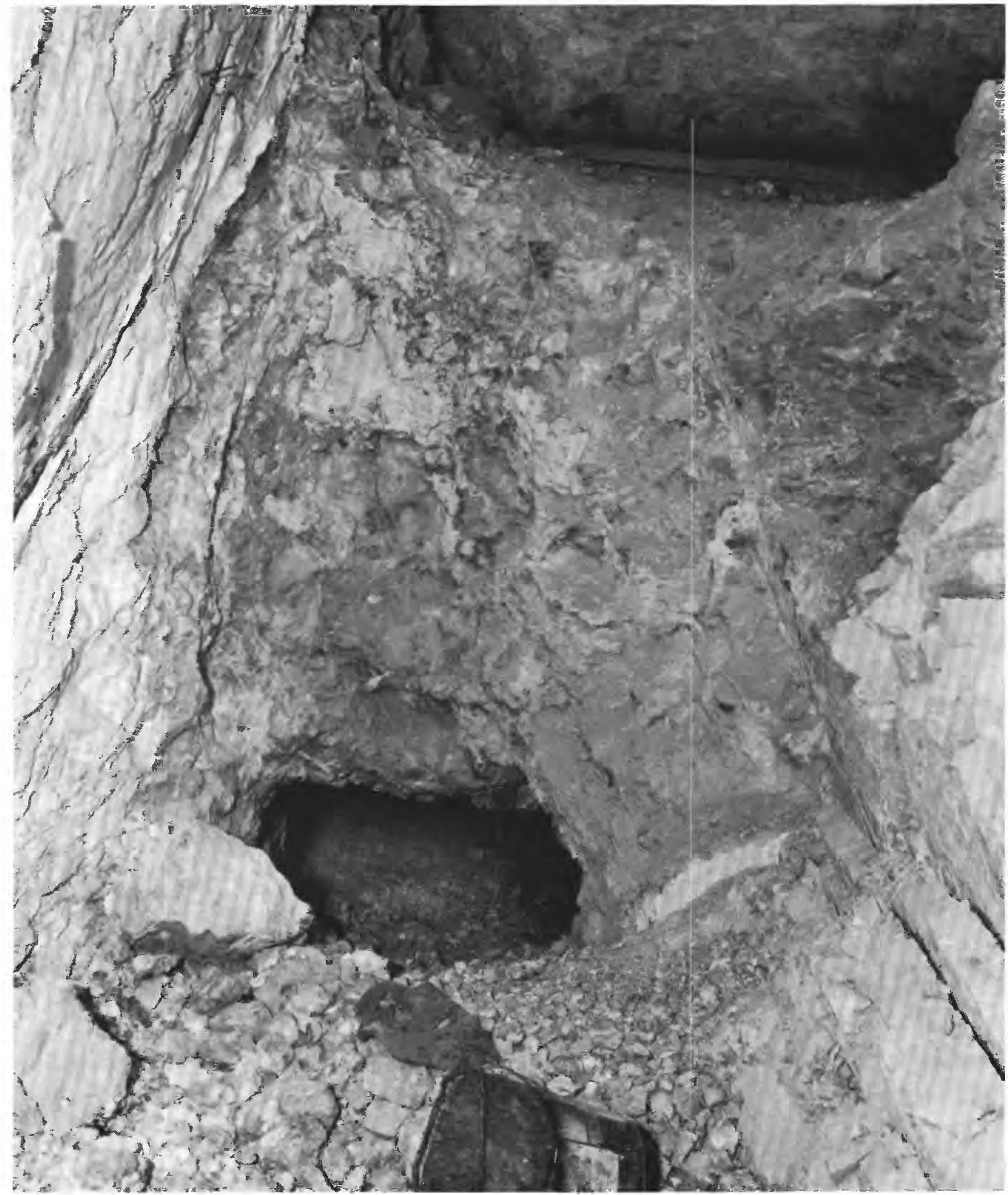

FrGURE 45-Brecciated fault contact between steeply dipping Paleozoic(?) limestone (on right) and granitic rocks of Cretaceous (?) age, at Hoping No. 1 incline, San Bernardino County, Calif. Rounded breccia fragments are coated by purple fluorite (dark), gypsum, and carbonate minerals. Hexavalent uranium minerals fill fractures in the breccia and replace limestone fragments, as shown by the lightcolored patches in the breccia zone. 


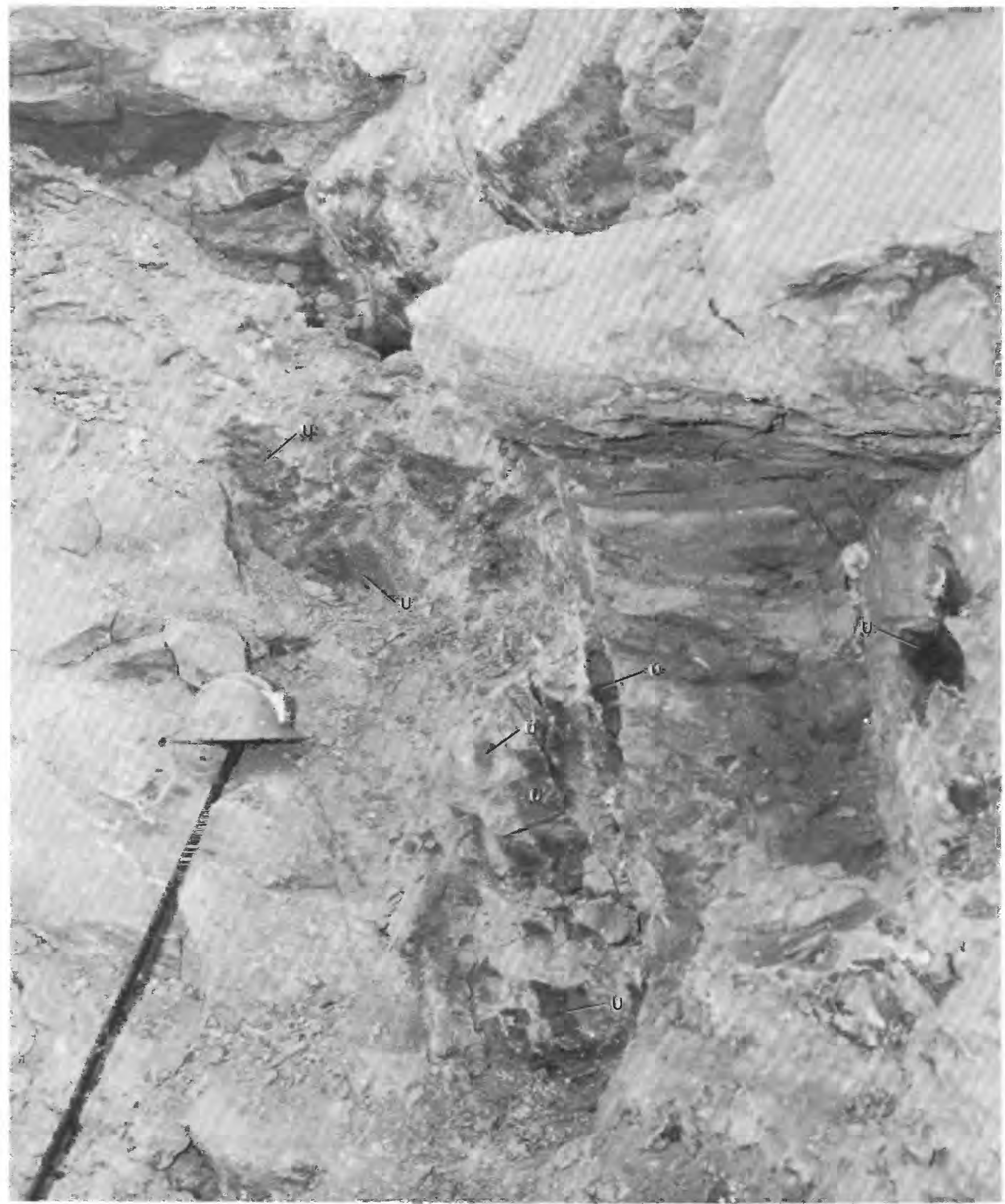

FIGURE 46.-Tabular breccia zone containing uranium minerals (U) in Madison Limestone of Mississippian age, Fuesner mine, Little Mountain district, Big Horn County, Wyo. 

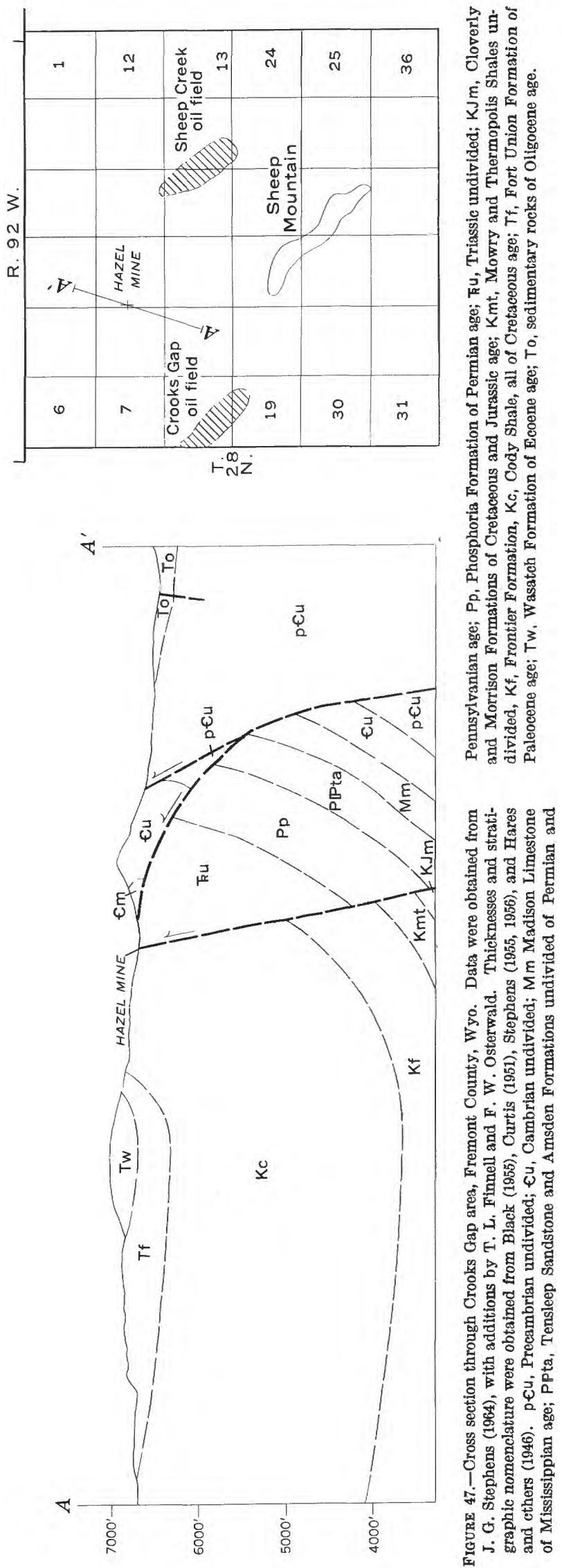


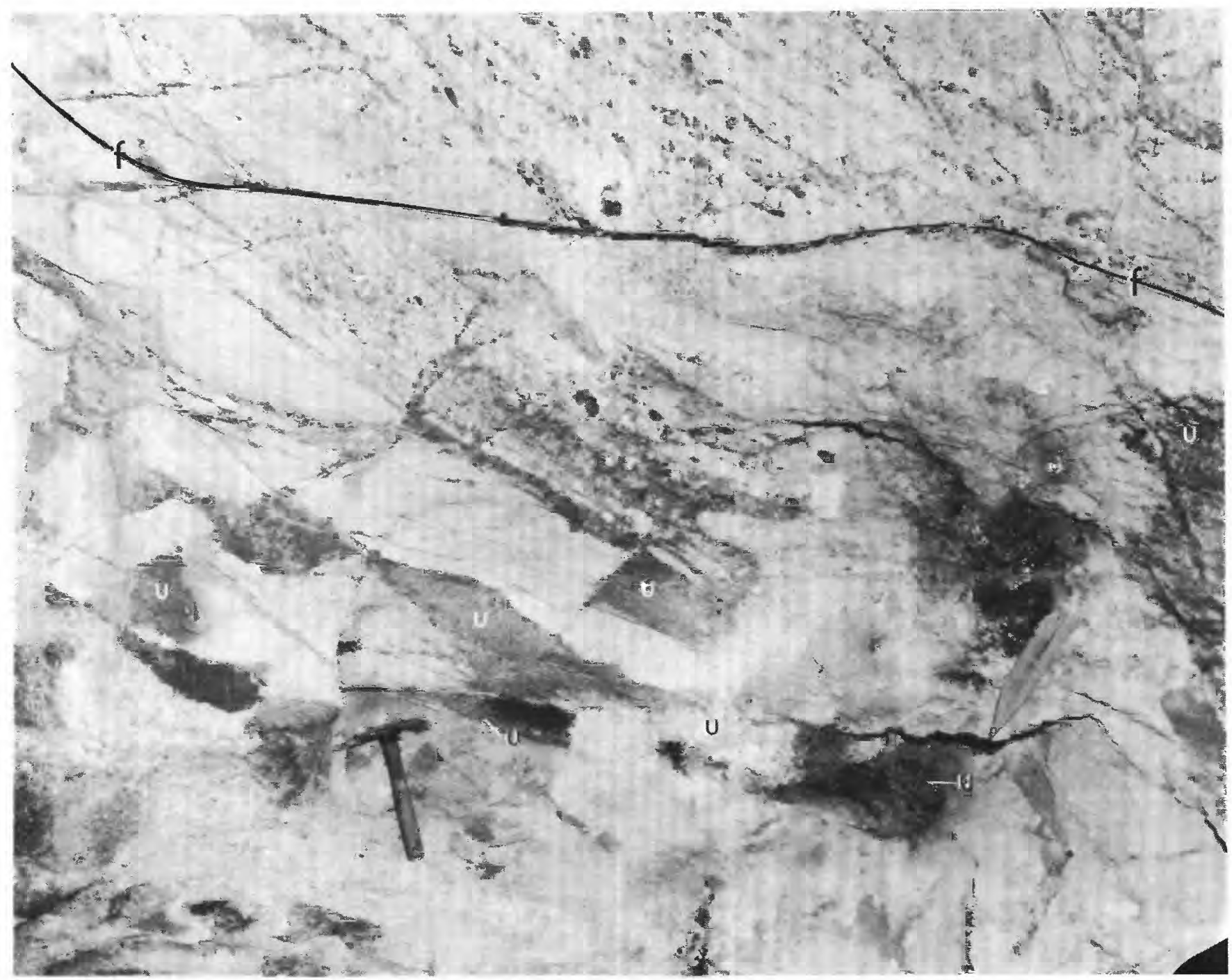

Figure 48.-Uranium ore body in fractured Tertiary (?) conglomerate and sandstone, Mary $\mathbf{L}$ claim, Tallahassee Creek district, Fremont County, Colo. Underlying sedimentary rocks of Tertiary (?) age are separated from overlying Precambrian rocks by a reverse fault (f). Black clots are highly radioactive, contain carbonaceous material, and are as much as 4 inches in diameter. Yellow uranium minerals (U) surround the clots, coat some fractures, and have impregnated favorable blocks of conglomerate. Black veinlets as much as 1 inch wide fill faults and contain gummite, green material with woody texture, and probable pitchblende.
Some of the uranium deposits in the Coeur d'Alene district, Shoshone County, Idaho, are on or near the crests of minor anticlines that parallel major anticlines. These deposits are closely associated with important base-metal veins. Individual silicified veinlets containing pitchblende fill fracture-cleavage planes and bedding-plane faults along the crests of the minor anticlines (E. E. Thurlow, oral commun., 1954). Hexavalent uranium minerals are associated with cinnabar along the crest of a large gently folded anticline at $\mathrm{El}$ Sotolar, Chihuahua, Mexico (Mencher, 1956, p. 12; Bain, 1950, p. 287). A normal fault and several parallel subsidiary faults cut the crest of the anticline; the mineral deposits are localized where the subsidiary faults are intersected by smaller transverse faults (G. W.
Bain, written commun., 1945; J. M. Hill, written commun., 1945).

The structural control for a uranium deposit on the Buckhorn claim, in Lassen County, Calif., and Washoe County, Nev., is also an anticline that is faulted but is different in scale and in structural setting from those in the Coeur d'Alene and El Sotolar districts. The deposit is in rocks of Tertiary age that dip steeply to the west on the west side of the Antelope Range. The host rock, a white tuff, is bent into a small plunging anticline, is silicified, and, in part, is stained buff by iron oxide. Small faults and joints, nearly parallel to the axial plane of the anticline, cut the tuff. Apparently, silica, iron, and uranium were introduced along the faults and joints. 


\section{FRACTURES CUTTING FAVORABLE HOST ROCKS}

The intersections of faults, joints, or fault zones with favorable rocks have localized many uranium-bearing veins. The rocks may be favorable for introduction of uranium because they are permeable, reactive, or brittle. One of the most important uranium-bearing vein deposits exhibiting the intersection of faults, joints, or fault zones with favorable rocks is the White King mine, near Lakeview, Lake County, Oreg. At the White King mine, the rocks are broken by faults belonging to two sets, one trending northwest, which contains the longest faults, and one trending north (Howard Dutro, oral commun., 1958). The northwest-trending faults are an extension of a belt of major faults northnorthwest of the mine area (G. W. Walker, written commun., 1956). In the mine, most of the uranium ore is in a thoroughly kaolinized tuff containing opal nodules in and near the faults; some ore is in agglomerate overlying the tuff.

Some uranium deposits consist of tabular zones of uranium minerals, with or without sulfides, disseminated in the walls of tight fractures. Examples of this kind of structural association are found in some of the deposits in the Precambrian Dripping Spring Quartzite, Gila County, Ariz. (Granger, 1955, p. 187-188; Kaiser, 1951, p. 7). The most promising deposits in the Dripping Spring Quartzite apparently were controlled by tight fractures and are within a few feet of discordant contacts between favorable siltstones and diabase intrusives (Granger, 1955, p. 187).

Intersections of vein-filled fractures and green altered biotite-quartz-plagioclase gneiss containing amphibolite pods have localized uranium minerals at the Two Sisters mine and at the R. H. D. claim, Central City district, Colorado (Sims, Osterwald, and Tooker, 1955, p. 17, 24, 28). During oxidation of the primary-vein minerals, metatorbernite was disseminated through the altered rock, but it is most abundant near the veinfilled fractures. The structural relations imply that the deposition of metatorbernite from solutions moving along the veins was controlled by the physical and chemical properties of the green altered gneiss. Other examples of the control of uranium deposits by the intersection of veins with favorable rock types are the Merry Widow and Apache Trail deposits, Grant County, N. Mex. (Granger and Bauer, 1956, p. 334, 338, 343-344), where veins cut altered diabase and basalt dikes. Some of the pitchblende veins in Golden Gate Canyon, Jefferson County, Colo., contain uranium only where they cut hornblende gneiss (Adams and Stugard, 1956).

The effect of increased permeability of fractured rocks is similar to the effect of more subtle structural controls for some uranium deposits that are not classified as veins. For example, in the Rex No. 1 mine, Temple Mountain district, Emery County, Utah, a roll ore body 4 to 6 feet thick in sandstone was adjacent to the south side of an almost vertical fault trending nearly east (figs. 49, 50, 51). Although some movement along the fault was of post-mineralization age, at least some of the uranium-bearing material was deposited along the fault (figs. 49 and 50) in a tabular zone 1 to 2 feet wide. As shown in figures 50 and 51 , ore in the fault extends upward from one side of the roll ore body; whether it also extends downward could not be determined. The Ran-Rex mine, Gas Hills district, Fremont County, Wyo., is another example of a similar type of structural control. As shown in figure 52, the mineralized bed, which is several feet thick, is part of a small horst. Circulating solutions were trapped by impermeable rocks beneath the ore body and by gouge along the faults.

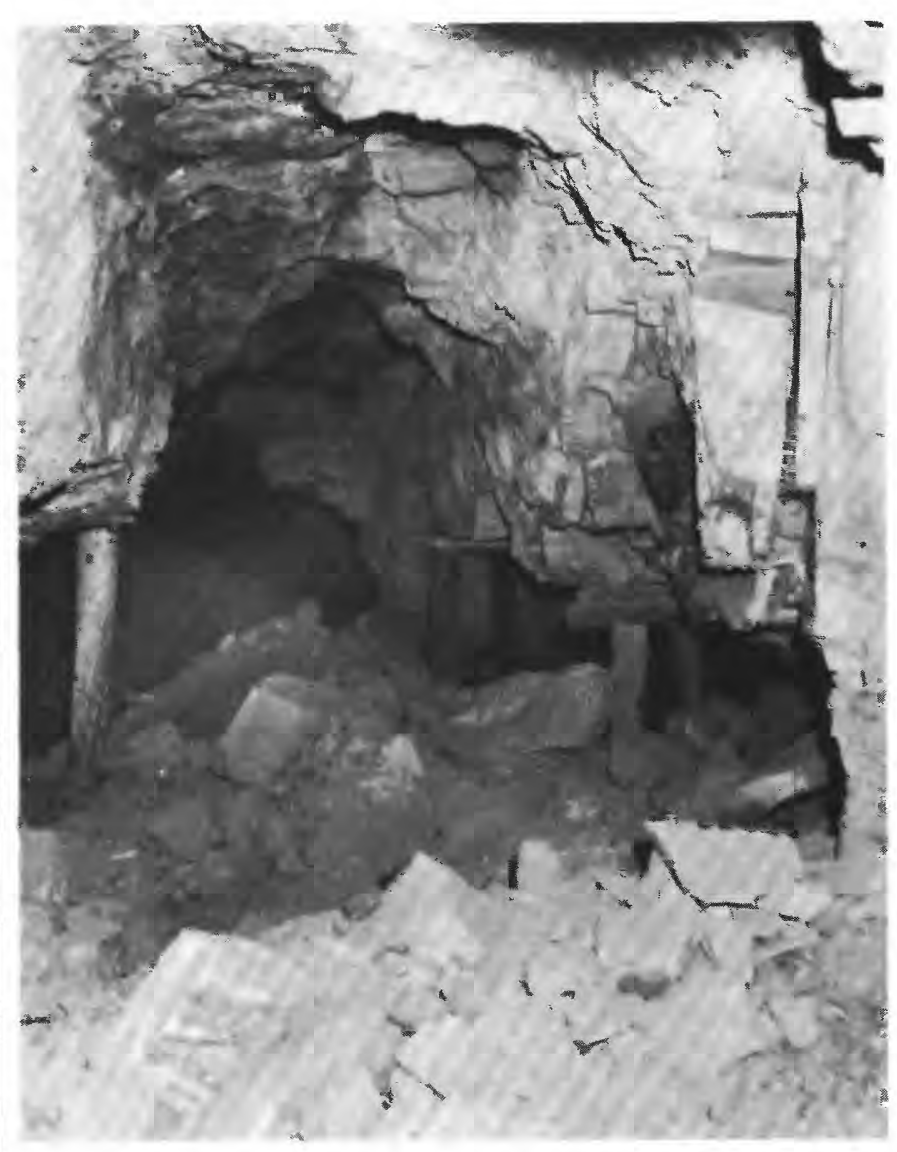

Frgure 49.-View west along length of stoped-out ore roll, showing fault along north (right) side of roll. Ore zone (dark), about 2 feet wide, is adjacent to south side of fault. Rex No. 1 mine, Temple Mountain district, Emery County, Utah. 


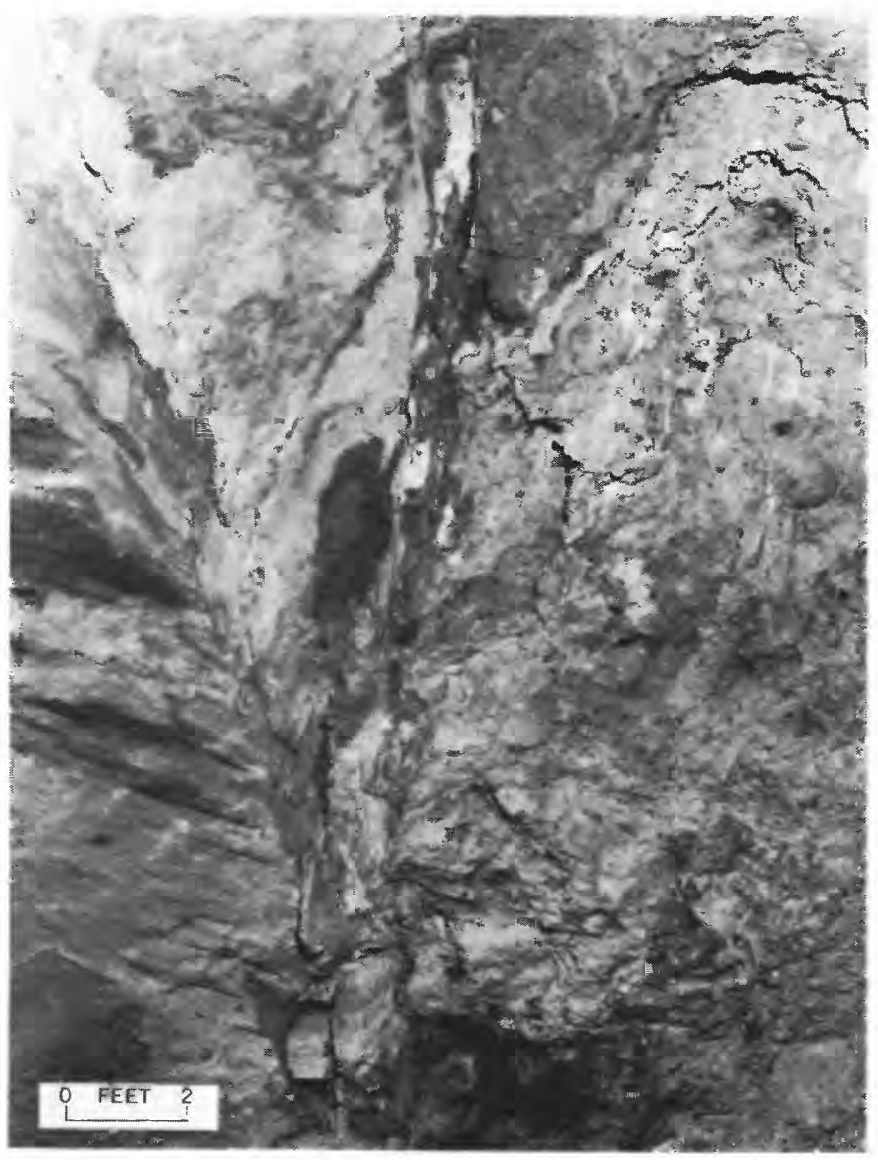

Figure 50.-Fault in back of stoped-out ore roll. Dark areas along fault are ore in irregular zone as much as 2 feet wide. Rex No. 1 mine, Temple Mountain district, Emery County, Utah.

Many pipelike uranium deposits are similar in structural setting and in genesis to tabular veins. These pipelike deposits occur in or near breccia pipes, at fault intersections, and in or near curves in fault planes. One of the largest known pipelike uranium deposits is in fractured syenite at the Gunnar mine, Saskatchewan. In the United States, the carrot-shaped uraniferous fluorite deposits of the Thomas Range, Juab County, Utah, are roughly similar to the shape of the Gunnar deposit. Other pipelike bodies, such as that of the Ridenour mine, Coconino County, Ariz., are curved (Miller, 1954) ; still others, such as that of the Woodrow mine, McKinley County, N. Mex., are complex deposits bounded by ring faults. Structural relations of some pipes and the distribution of uranium within the pipes are illustrated by some of the following examples:

1. Some of the fluorite pipes in the Thomas Range, Juab County, Utah, contain small amounts of uranium (Wilmarth and others, 1952, pl. 13; Staatz and Osterwald, 1959, fig. 10). These pipes cut tilted, highly faulted dolomite of Paleozoic age and rhyolite porphyry of Tertiary age (Thurston and others, 1954, p. 27); most pipes are in or within a few feet of faults or intrusive breccia of Tertiary age (Staatz and Osterwald, 1959, p. 48). Within the pipes, uraniferous fluorite replaces dolomite along channelways produced by intense fracturing. Uraniferous fluorite of ore grade occurs near the surface in some pipes, but it rapidly decreases in grade with depth.

2. The Woodrow mine, McKinley County, N. Mex., is in a nearly vertical pipelike structural feature bounded by a ring fault in sandstone (Argall, 1954). Uranium minerals, pyrite, and minor amounts of other minerals are in the gouge and breccia formed by the downfaulting of a sandstone bed 25 to 40 feet (Cook and Wylie, 1956, p. 113). This pipe differs from those in the Thomas Range in that the uranium minerals cement broken rock rather than replace the country rock around and near channelways.

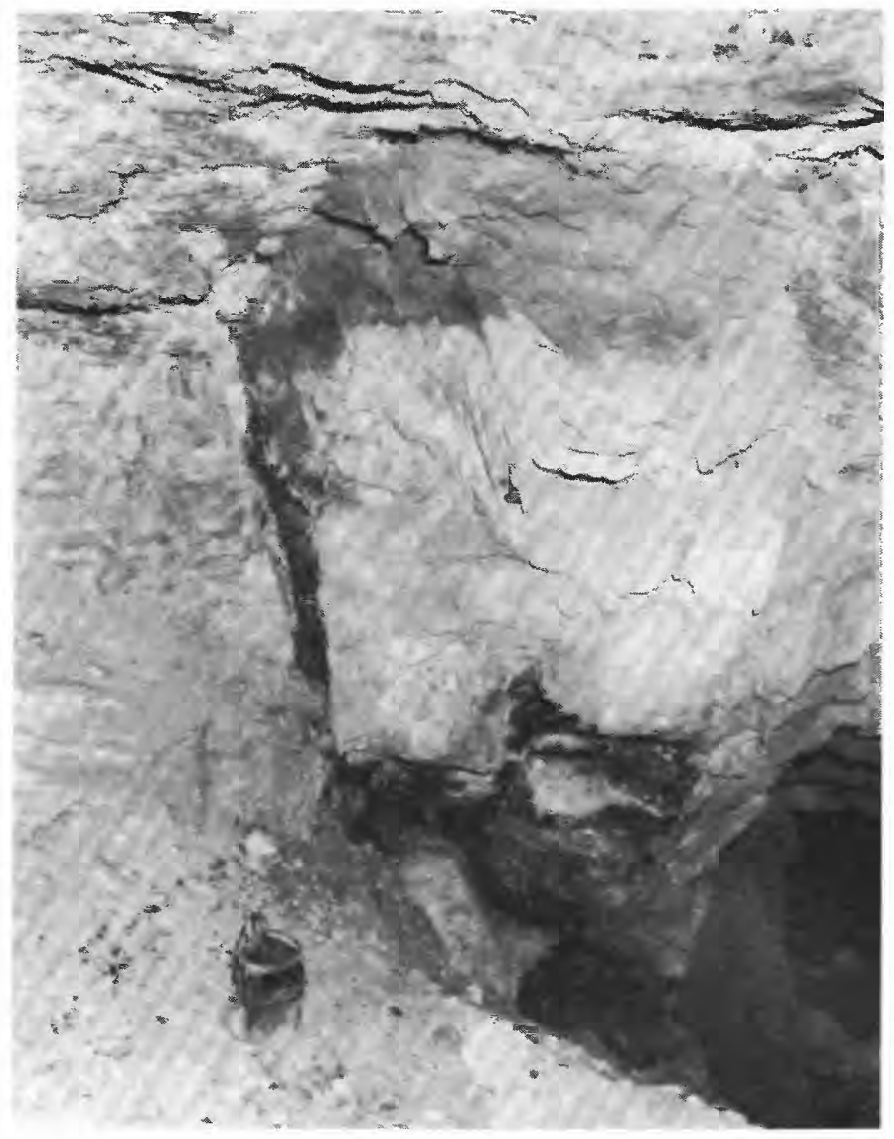

Figure 51.-Uranium ore (dark) about $1 \frac{1}{2}$ feet wide, in fault at east end of ore roll, Rex No. 1 mine, Temple Mountain district, Emery County, Utah. 


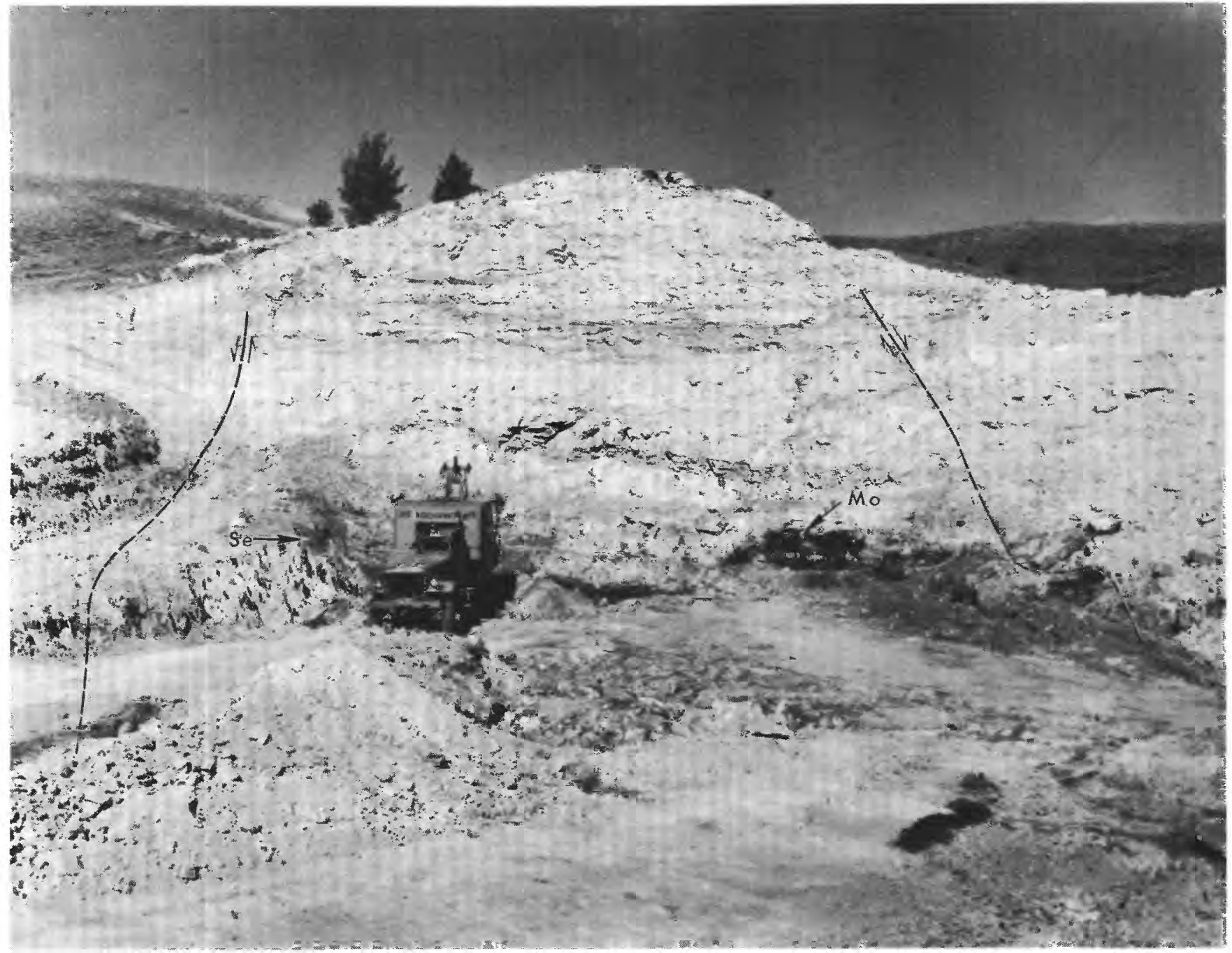

FIGURE 52.- View east of uranium ore body (medium-gray layer beneath shovel) within permeable rocks of Eocene age in uplifted fault block at Ran-Rex mine Gas Hills district Fremont Counts, Wro.

3. Many pipelike mineral deposits that have similar structural characteristics are known in western Utah and northwestern Arizona. Some of these deposits contain uranium minerals, but only a few contain ore-for example, the Orphan Lode, in Grand Canyon National Park, the Ridenour mine, in Coconino County, Ariz., the Hack Canyon claim, in Mohave County, Ariz., the Copper Mountain claim, in Mohave County, Ariz., and the Staats Fluorspar mine in Beaver County, Utah. Most of these pipes are within a few miles of or adjacent to a set of major high-angle faults (map by James Gilluly and C. B. Hunt, in Hunt, 1956, fig. 37). The mineral deposits in most of the pipes in Utah and Arizona are similar to that in the Woodrow pipe because they are bounded by roughly circular elliptical fractures. The uranium minerals
Faults are of Eocene age as demonstrated by left fault which does not cut uppermost beds. Selenium (Se) and molybdenum (Mo) blooms appear above ore body. in most pipes are in and near the bounding fractures (fig. 53) ; an exception is at the Staats Fluorspar mine where 4-valent uranium minerals are distributed throughout altered tuff that is in contact with brecciated dolomite along a curving fault.

The Ridenour mine is in a block about 6 miles wide bounded on the west by the Hurricane fault and on the east by the Toroweap fault; the mine is only $11 / 2$ miles east of the Hurricane fault. The fact that near the mine the Hurricane fault bends westward suggests that the Ridenour mine is located where subsidiary fractures caused by the bend provided access for solutions (fig. 54). Similarly, the Orphan Lode mine, Arizona, is near the major high-angle Bright Angel fault. 


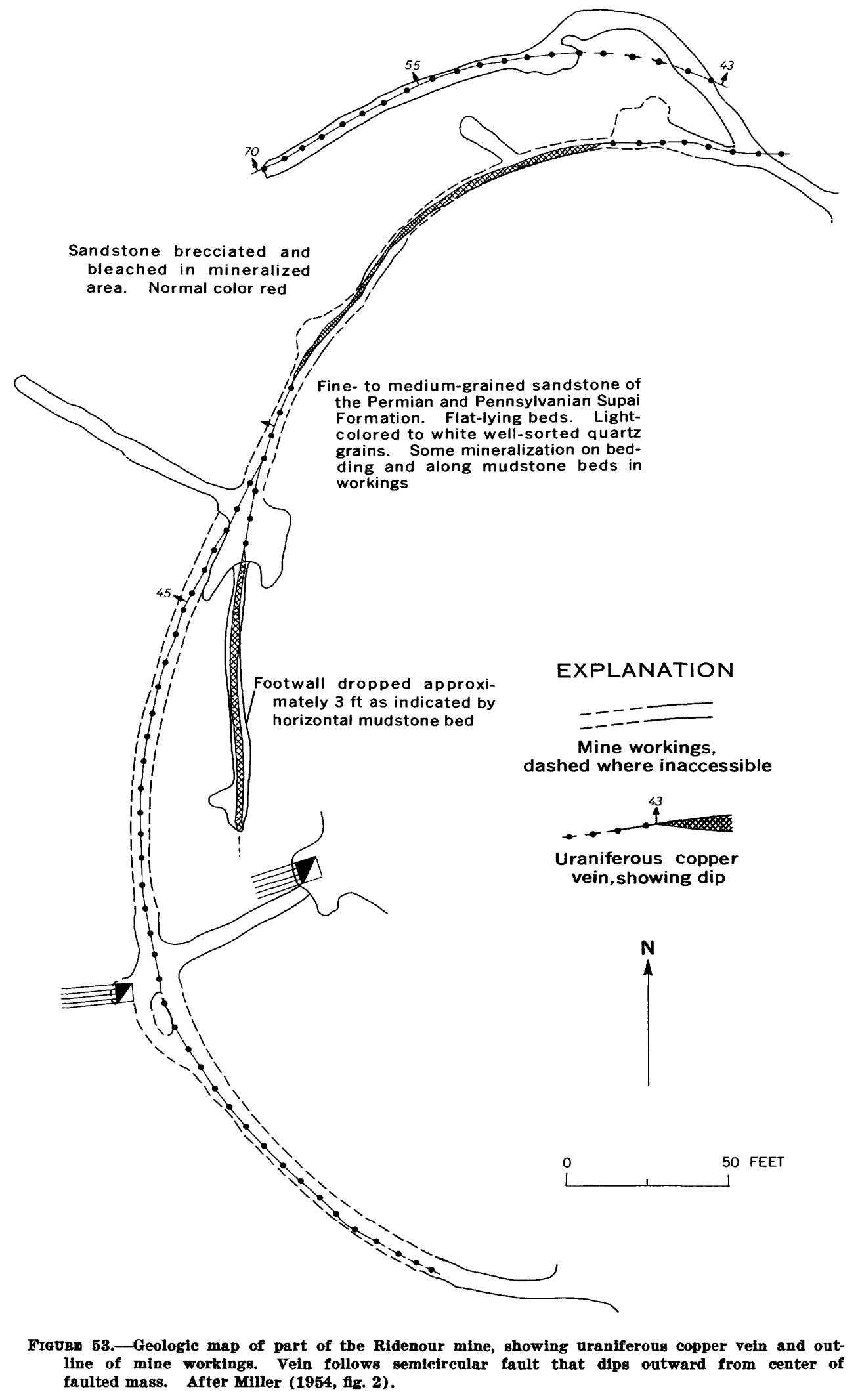




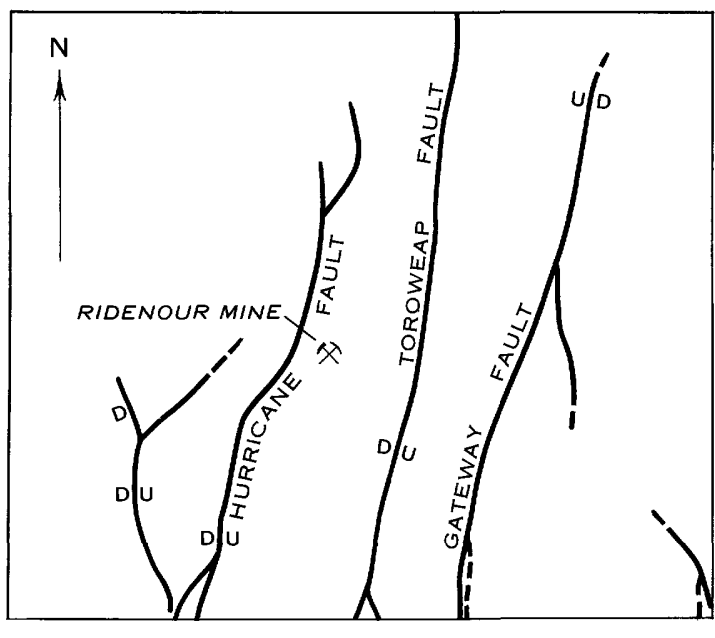

0 5 MILES

Figure 54.-Location of Ridenour mine with respect to Hurricane and Toroweap faults, Coconino County, Ariz. After Lovejoy (1954, fig. 5).

The Hack Canyon claim, Arizona, about 15 miles north of the Grand Canyon National Monument boundary, is a few miles east of the Sevier fault, at a place where the fault bends markedly westward and splits into several subsidiary faults (Koons, 1945, pl. 1). The deposit is in a downdropped irregular block of sedimentary rock, and the ore body itself is an irregular pipelike mass about 12 feet wide beside a curve on a fault plane (fig. 55). Within the pipelike mass, uranium and copper minerals cement breccia and impregnate porous sandstone.

The pipes and pipelike uranium-bearing deposits have various origins. Some uranium deposits, such as the Dell pipe in the Thomas Range, Utah, are in or adjacent to diatremes, but others, such as some of those in the Temple Mountain district, Utah, are in collapse structures perhaps resulting from solution of limestone and later subsidence (Keys and White, 1956, p. 294-295). Still others, for example the Bell Hill mine in the Thomas Range, Utah, probably result from reaction of late-stage volcanic emanations with the wallrocks (Staatz and Osterwald, 1959). Some pipelike ore shoots, including the Los Ochos deposit, are related to brecciation near faults. The pipelike deposits seem to result from various processes; their form does not indicate any particular mode of origin either for the structures or for the mineral deposits.

Fault zones and joints in sedimentary rocks overlying salt domes contain uranium-bearing veins in some places. Very few precise structural data concerning uranium deposits related to salt domes are available, and virtually all have come from study of drill records in the Gulf Coast region of Texas and Louisiana. Ura- nium minerals, partly in fractures and partly in tabular veinlike masses, have been found in the sedimentary rocks overlying the Piedras Pintas and Palangana salt domes, Texas. Unidentified radioactive precipitates from radium-bearing brines, probably derived from uranium minerals, are associated with several other salt domes near Houston, Tex. (Hill, 1953, p. 202-203). These deposits probably result from the easy access to favorable rock units that is provided for uranium-bearing brines by abundant faults and joints.

\section{STRUCTURAL ENVIRONMENTS OF URANIUM DISTRICTS}

Uranium districts, as well as other metalliferous districts, occur in characteristic structural environments. These environments seem to be superimposed on larger regional structural features, and recognition of them should assist in finding new uranium districts. A special study has been made of the relation of fault and fold patterns of some uranium districts to regional structures in the United States.

Preliminary studies of uranium-bearing vein districts in the Cordilleran foreland (Osterwald and Dean, 1961) suggested that epigenetic uranium districts can be related to several structural patterns: (1) flanks of largescale anticlinal uplifts (100 to several hundred miles long) where subordinate structures are parallel to the major structure, (2) flanks of large-scale uplifts where smaller structures are arranged en echelon, (3) crests of large-scale anticlines, (4) conjunctions of major structures where trends intersect or merge, (5) troughs of major basins. The use of the terms "large-scale," "intermediate-scale," and "small-scale" in describing structural features in this report conforms to the definitions by Osterwald and Dean (1961, p. 340). Most uraniumbearing vein districts seem to have a structural environment in which certain types of subsidiary intermediateto small-scale structural features are related to one or two large- to intermediate-scale features.

Within the Cordilleran foreland, uranium-bearing vein deposits are known in districts that exhibit one or another of these five structural patterns, but they are common only in districts characterized by the first two structural patterns. Also, the same structural pattern may characterize a vein district or a sandstone-type district in which veins are scarce or lacking. For example, the uranium district along the east flank of the Front Range uplift, Colorado, and that along the north flank of the Sweetwater arch, Wyoming, are both located along the edge of large-scale uplifts where smaller structural features are arranged en echelon. However, the deposits in the uranium district along the Front Range are mostly in veins, and those in the district along the Sweetwater arch are mostly disseminated (sandstone-type). 


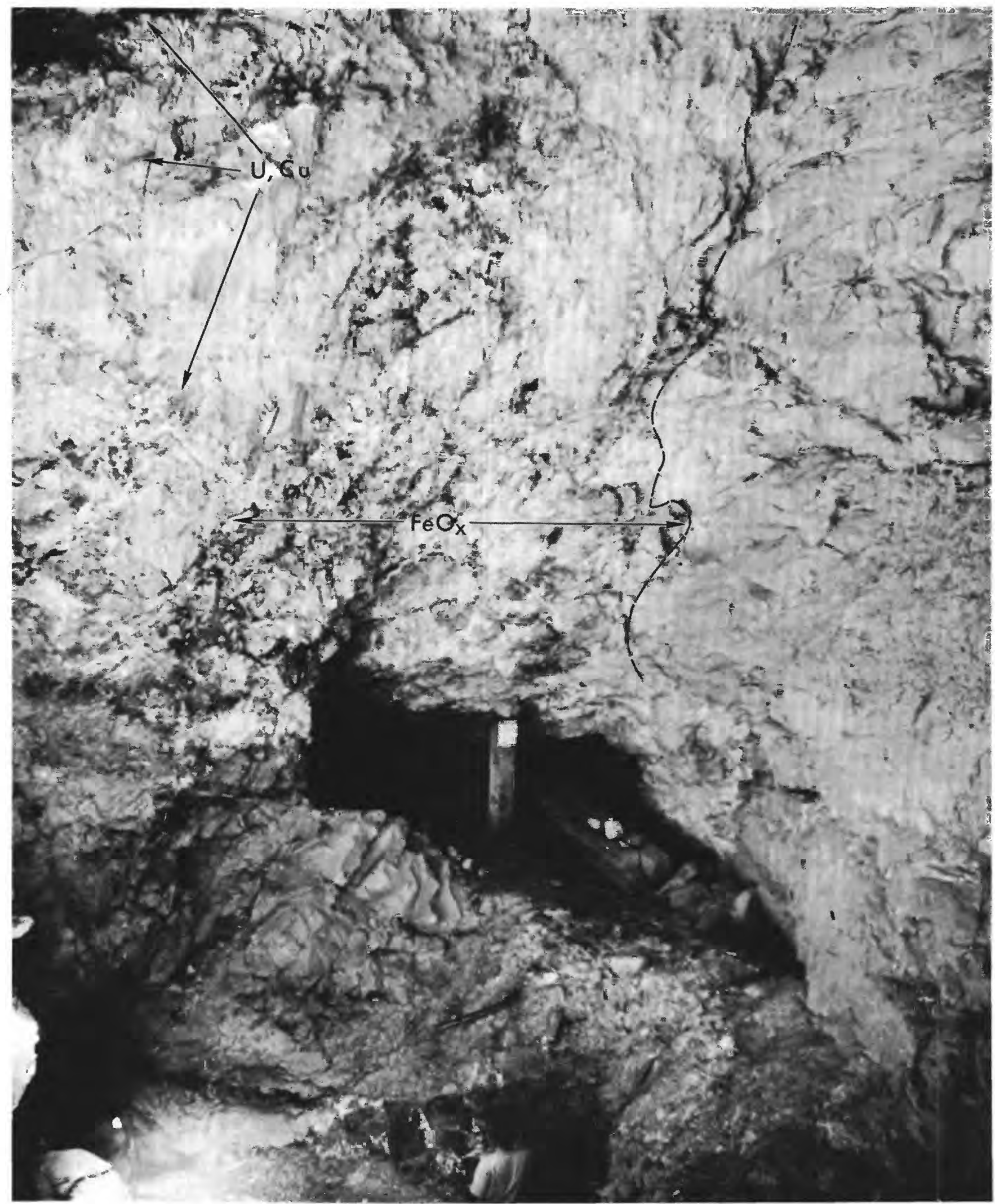

Figure 55.-Fast face of opencut at Hack Canyon mine, Mojave County, Ariz., showing fault in sedimentary rock of Paleozoic age along south edge of pipe (heavy dashed line), with heavy limonitepicture. Most of the hexavalent uranium minerals and copper min erals ( $\mathrm{U}, \mathrm{Cu}$ ) fill fractures in downdropped block, but some form nodules in the rock. 
Most regions outside of the Cordilleran foreland have not been studied in sufficient detail to determine whether the above relations exist, but some districts appear to have characteristic structural patterns of large-scale structural features associated with smaller structural features.

\section{DISTRICTS ADJACENT TO LARGE-SCAIE STRUCTURAT FEATURES}

The Front Range contains many uranium-bearing veins in Precambrian crystalline rocks and in Mesozoic sedimentary rocks. Most of the vein deposits are in areas of numerous en-echelon northwest-trending faults; some of the faults offset the north-trending monocline bordering the range (which is a large-scale uplift) on the east and extend into folds in Paleozoic and Mesozoic rocks (Osterwald and Dean, 1961). The veins in the Central City district fill some of the fractures in a complex fault system (Sims, 1956, p. 743) and do not seem to be directly related to the northwest-trending faults. Other districts in the Front Range, such as those along Ralston Creek (Sheridan, 1956), in Golden Gate Canyon (Adams and Stugard, 1956, p. 194), and near Idledale, Colo. (Theobald and King, 1954, p. 223-224), are related to northwest-trending intermediate-scale faults (fig. 56). In some of these districts, for example the Ralston Creek district, the northwest-trending faults either consist of complex networks of faults and joints

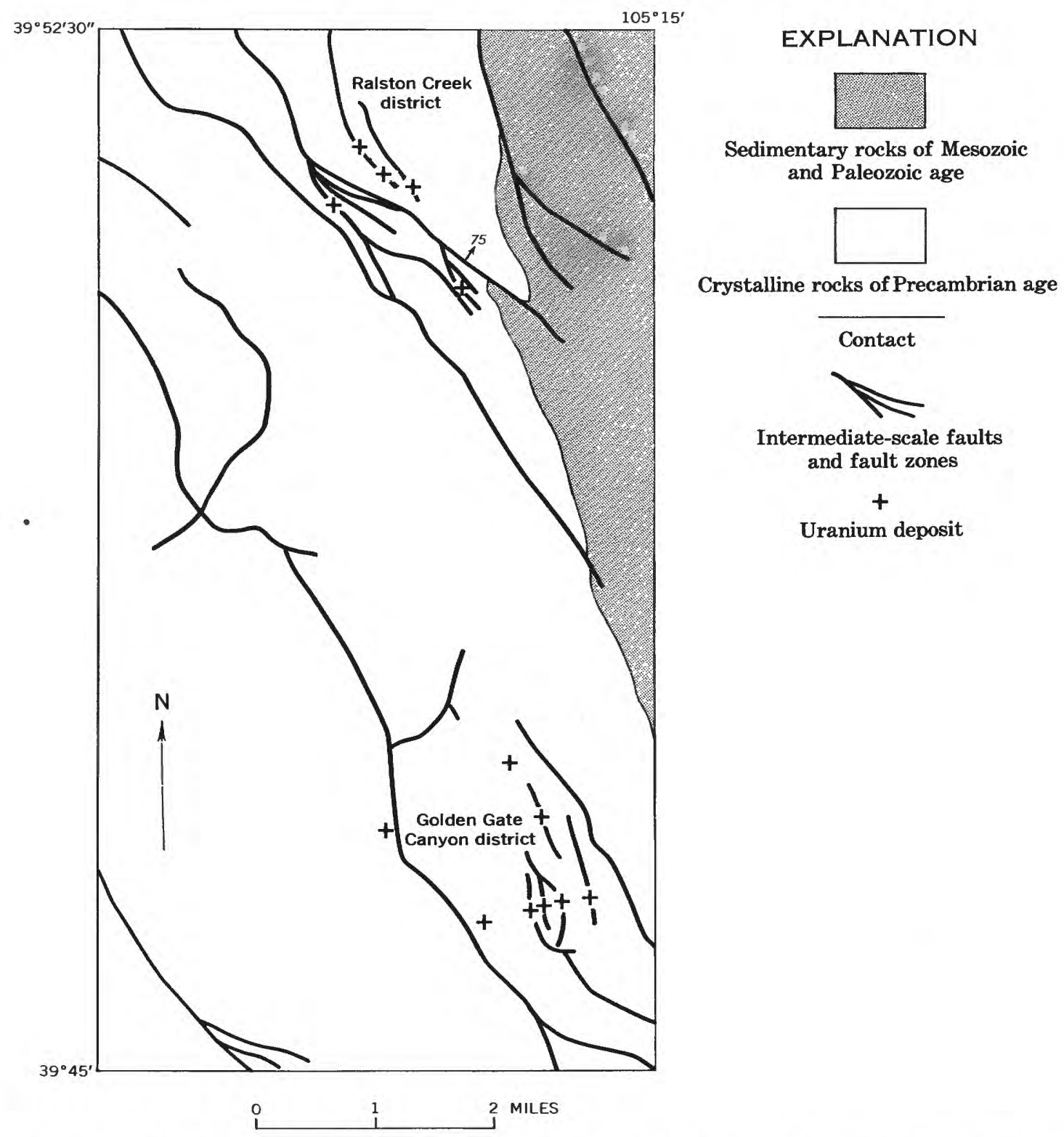

FIGURk 56.-Location of Ralston Creek and Golden Gate Canyon districts, Jefferson County, Colo., with respect to intermediate-scale faults and fault zones. After Sheridan and others (1958, fig. 2). 
or they change trend (Sheridan, 1956, p. 132). Within the Front Range other deposits are localized by small fractures, either parallel to the northwest-trending faults such as that at the F.M. D. mine (Theobald and Guilinger, 1955) or intersecting the northwest-trending faults such as that at an unnamed mine near Copperdale (King, 1954, p. 174). A few of the deposits within the Front Range have been described as related to a large thrust fault parallel to the margin of the range. Smallscale faults, within the overthrust block and presumably subsidiary to the large fault, may have localized the deposits at the Mann mine near Morrison, Colo. (Goldstein, (1957, p. 778-781), and at the Leyden Coal mine near Golden, Colo. (F. A. McKeown and A. J. Gude, written commun., 1951). As shown in figure 57, however, the major fault probably dips at a high angle and is not a thrust fault (Osterwald, 1961, p. 228). A small fault at the Pallaoro mine (fig. 57) is one of the enechelon northwest-trending faults characteristic of the Front Range district.

The structural pattern in the Gas Hills uranium district (fig. 58), along the north flank of the Sweetwater arch uplift, in central Wyoming, is somewhat similar to that of the Front Range; however, the deposits within them are dissimilar because of the different types of host rocks. The Gas Hills district, which was mapped and described by Zeller, Soister, and Hyden (1956), contains numerous deposits of uranium in porous sedimentary rocks of Tertiary age and at least one small vein deposit on the John claim. The district is marginal to the east-trending Sweetwater arch uplift (Osterwald and Dean, 1958a) and is characterized by a series of en-echelon northwest-trending folds and faults in the rocks flanking the north side of the uplift and by a series of east-trending faults parallel to the uplift (Zeller, 1957).

The Maybell-Lay (Sugarloaf) district, Moffat County, Colo. (Bergin, 1955; Bergin and Chisholm, 1956), containing many disseminated impregnation and replacement deposits in porous sedimentary rocks of Tertiary age as well as a few veins in gouge and brecciated rocks, is another example of a uranium district near subordinate structural features flanking large-scale structural features (Osterwald and Dean, 1961; Everhart, 1956a, p. 93). This district, which is marginal to the large-scale Axial Basin anticline (fig. 59), has a complicated structural history. Post-Miocene subsidence folded into a syncline the rocks of Miocene age that overlie the anticline; marginal and parallel to the syncline, and genetically related to it, are en-echelon zones of anticlines, synclines, and small faults (Sears, 1924; Bergin, 1955; p. 176-178). Other faults and small folds are transverse to the trend of the major syncline. Some of the faults offset the synclinal axis.

The close spatial and genetic relations between the deposits and structural features in the district were described clearly by Bergin (1955, p. 179): "Megascopic examination of mineralized and barren sandstone samples show no significant difference in grain size, sorting, mineral assemblage, or cementing material, except for the presence of uranium minerals. Since the known uranium occurrences are on the steep north flank of a syncline and adjacent or in proximity to normal faults, it is believed that localization of uranium from solutions moving through the Browns Park formation may have been controlled by the presence of these structures $* * *$. The occurrences of uranium along faults, near diastems, and adjacent to some calcareous cemented sandstone masses indicates that changes in permeability and porosity of the host rocks may also have influenced the localization of uranium."

A uranium district in the Province of Mendoza, Argentina, which includes the Soberania, Independencia, and President Perón deposits, is somewhat similar to that of the Maybell-Lay district. The district in Mendoza is along the western flank of a large syncline. Sedimentary rocks of Oligocene and Miocene age in the core of the syncline are in contact with sedimentary rocks of Triassic age along a large fault bounding the margin of the syncline. The uranium deposits are within minor shear and breccia zones along the fault (Belluco, 1956, p. 85-87; Angelelli, 1956, p. 71-72).

The uranium-bearing veins, as well as other types of uranium deposits, in Cane Springs Canyon, south of Moab, Utah, are within a district having a structural pattern somewhat analogous to that of the Maybell-Lay district. The Cane Springs district is on the northeast limb of the Cane Creek anticline (Kelly, 1955, fig. 2). Steeply dipping normal faults that are parallel to the anticlinal crest contain uranium-bearing veins (O. M. McRay, written commun., 1958, revised by Y. W. Isachsen). Hexavalent and tetravalent uranium minerals, copper minerals, and vanadium minerals coat fractures and carbonaceous material in fault gouge and occur in brecciated sandstone and arkose along and between faults (Hinrichs, 1954, p. 35-36). Similarly, the Cashin mine, Montrose County, Colo., has a copper- and silverbearing vein containing small amounts of uranium emplaced in a fault marginal to and parallel with the Paradise Valley anticline (L. P. Riley and J. P. Owens, written commun., 1957).

The uranium deposits in the Taft-McKittrick district, California, are additional examples of control by subordinate folds and faults parallel to a large-scale fault. 

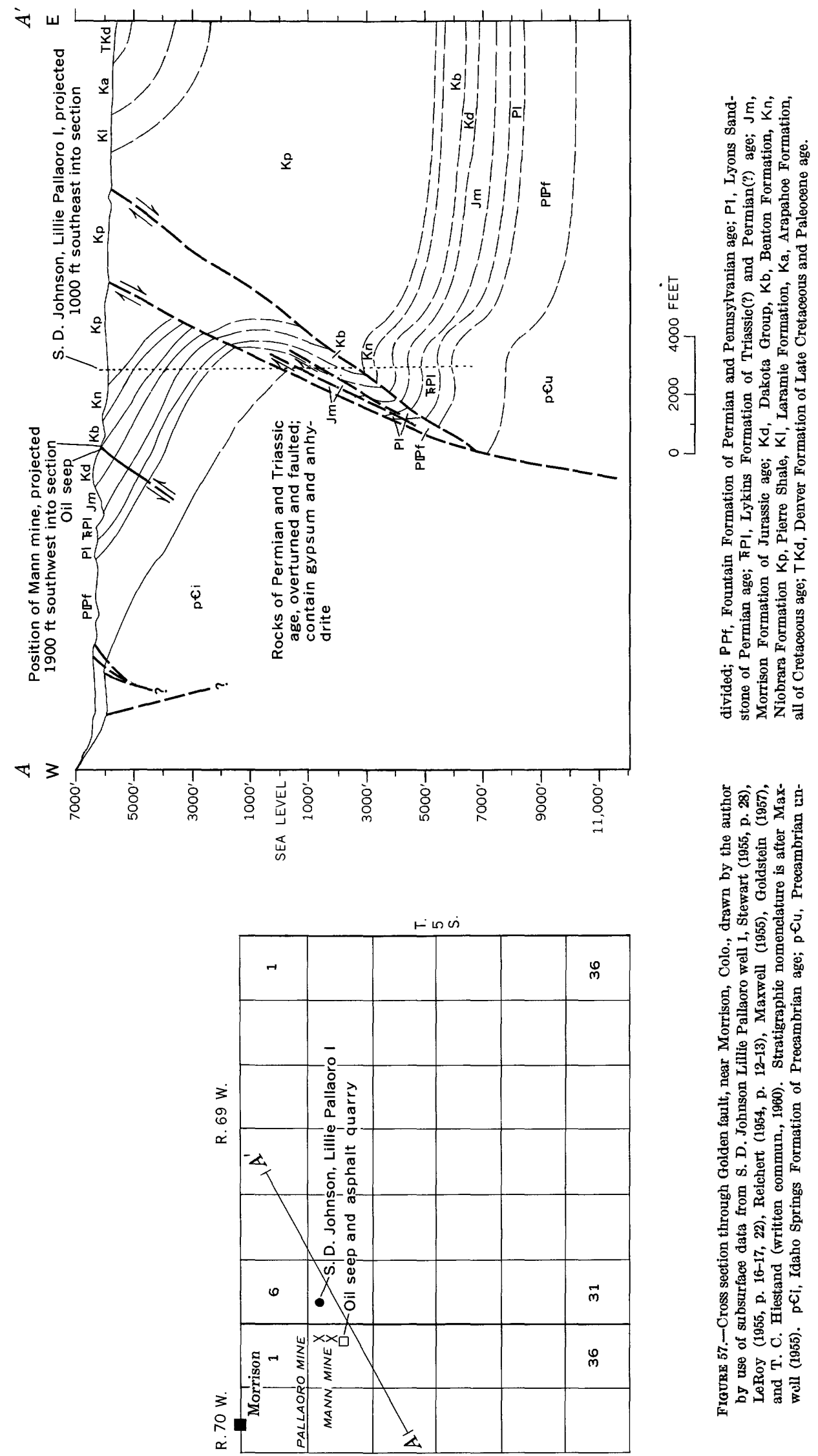
Uranium-bearing veins, as well as other kinds of epigenetic uranium deposits, are associated with a series of long anticlines and synclines on the northeast side of the San Andreas fault; most of the folds are parallel to the fault. Uranium deposits that have some veinlike characteristics, for example, the Surprise No. 1 and the Tres Amigo claims, were localized by small faults, fault zones, and joints parallel with and related to the folds.

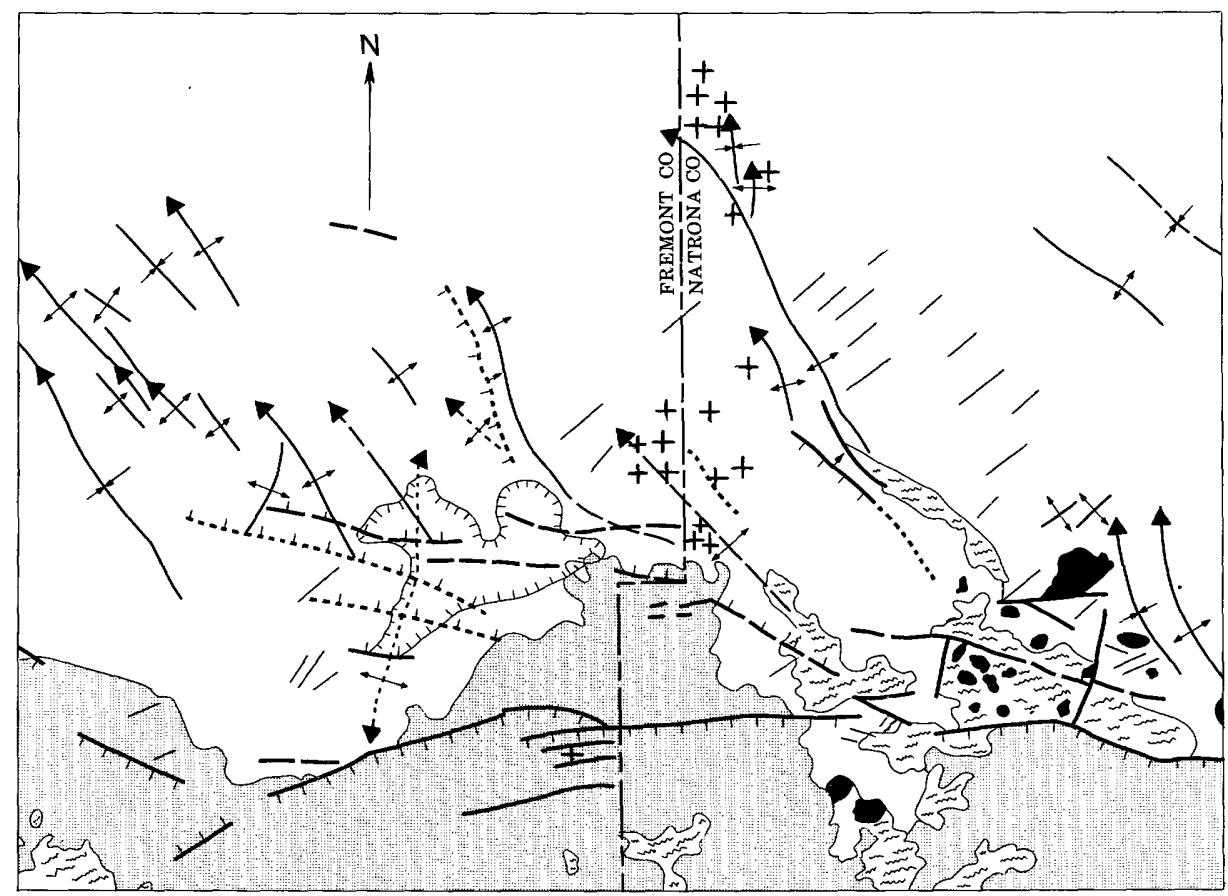

0 5 MILES

EXPLANATION
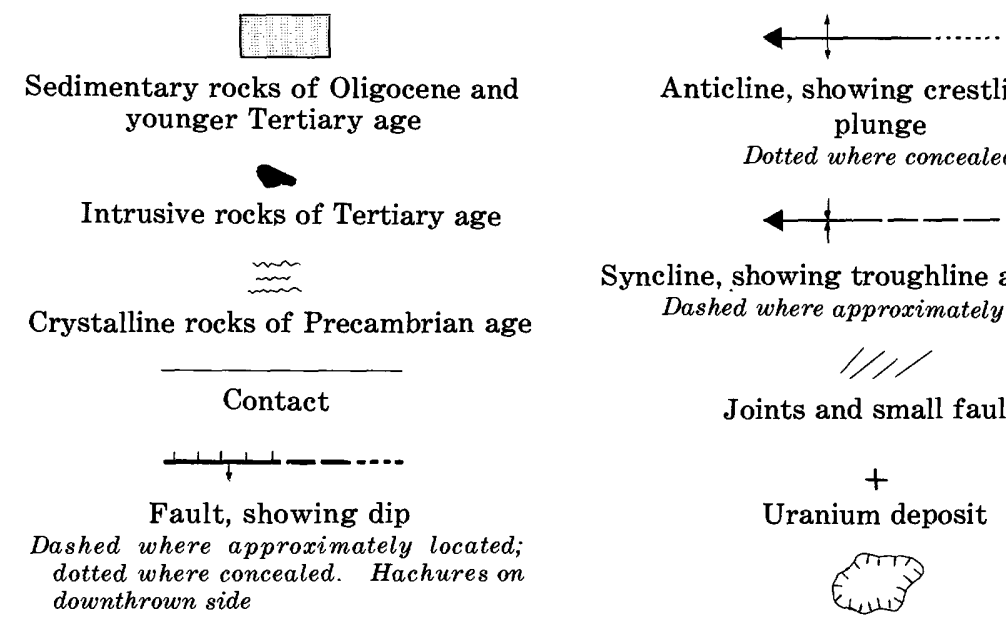

Anticline, showing crestline and plunge

Dotted where concealed

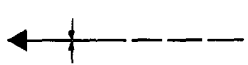

Syncline, showing troughline and plunge Dashed where approximately located

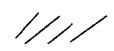

Joints and small faults

$+$

Uranium deposit

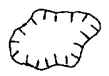

Group of uranium deposits

FIGURE 58.- Structural pattern of Gas Hills district, Natrona and Fremont Counties, Wyo. After Osterwald and Dean (1958a). 


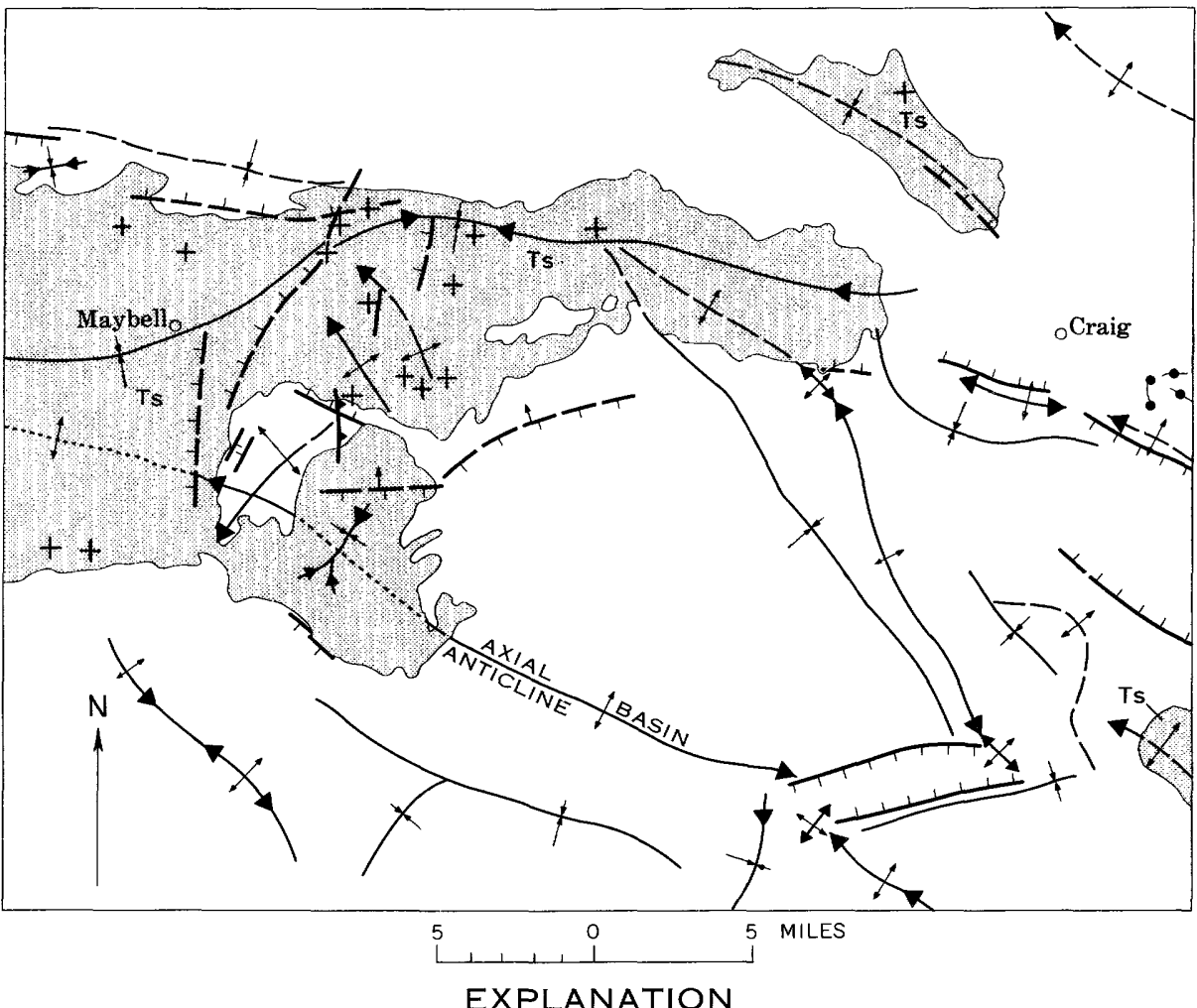

Contact

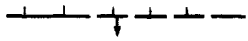

Fault, showing downthrown side and dip Dashed where approximately located

Thrust fault

Sawteeth on overthrust plate

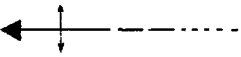

Anticline, showing crestline and plunge

Dashed where approximately located; dotted where concealed

Figure 59.- Structural pattern of Maybell-Lay (Sugarloaf) district, Moffat County, Colo. Stippled areas (Ts) are sedimentary rocks of Miocene age. Blank areas are sedimentary rocks of Late Cambrian to Eocene age. After Osterwald and Dean (1958b).

\section{DISTRICTS IN CRYSTALLINE-ROCK MASSFS}

The Boulder batholith district, Montana, is the best example in the United States of a uranium-bearing vein district characterized by subparallel faults and fault zones within an intrusive mass. Uranium-bearing veins are restricted to the northern part of the batholith and consist of silicified fault zones trending east and northeast that were sporadically mineralized with uranium and other metals (Becraft, 1956b, p. 119-121). Late movements, in part of the intermineralization age, brecciated the siliceous vein material (Roberts and Gude, 1953a, p. 73, 77-78) and also displaced the siliceous fault zones on cross faults that trend northwest to northeast. These cross faults have displacements of as much as several hundred feet (Roberts and Gude, 1953b, p. 151). Although they demonstrate late movement, these faults trend parallel to aplite dikes in the batholith (Thurlow and Reyner, 1950, pl. 2); this parallelism shows that the structural trend was established early. An underground map of the Free Enterprise mine indicates that the sporadic lentils of uranium minerals along the veins may be related to zones of closely spaced cross faults 
(Thurlow and Reyner, 1950, pl. 2). Uranium minerals probably were associated with cross faults in other mines of the district as suggested by the work of Thurlow and Reyner (1952) in the Lone Eagle, Harry S., G. Washington, and King Solomon Ridge claims. According to Thurlow and Reyner (1952, p. 24-26), the uraniumbearing lenses at the W. Wilson mine occupy tension fractures caused by horizontal movement along a northeast-trending siliceous fault zone. Tetravalent uranium minerals near fractures cutting veins in the Lone Eagle mine were also noted by Wright and Shulhof (1957, p. $117)$ and were shown on underground maps of the mine (Wright and others, 1954, p. 15).

The uranium district on the Spokane Indian Reservation, in northeastern Washington, is associated with a faulted and sheared intrusive rock contact. The known deposits in the district are distributed along the contact between intrusive granitic rock and metamorphic rock (G. E. Becraft and P. L. Weis, written commun., 1958), at places where the contact is faulted or sheared (Norman, 1957). Most of the uranium in the district is in metamorphic rock adjacent to the contact, but some is in faulted sedimentary, rock of Oligocene age near the contact (G.E. Becraft and P. L. Weis, written commun., 1958).

Swarms of en-echelon diabase, basalt, and rhyolite dikes within granite of Precambrian age characterize the structural pattern of the White Signal district, New Mexico (T. G. Lovering, 1956, fig. 50). Small faults and joints are common within the district, and many are filled with quartz veins. Displacement on the faults is as much as 60 feet (Granger and Bauer, 1956, p. 333 ). Where cut by quartz veins, the diabase dikes are impregnated with hydrous iron oxides and silica and are more resistant to weathering and more brittle than unaltered dikes (Granger and Bauer, 1956, p. 334). Hexavalent uranium minerals permeate some altered dikes, such as that at the Inez claim, and coat fracture surfaces and cavities in and near intersections of dikes with quartz-pyrite veins (Granger and Bauer, 1956). A small fault along the footwall of a diabase dike controlled the deposition of uranium minerals at the Apache Trail claim. The structural pattern of the White Signal district is similar to that of the Boulder batholith except that dikes rather than siliceous "vein zones" occupy major fractures.

\section{DISTRICTS WITH LINKED TENSION FRACTURES BE- TWEEN LARGE-SCALE FAULTS OR SHEAR ZONES}

A few uranium-bearing vein districts in the United States are characterized by linked tension fractures between parallel faults or fault zones; among these are the Cochetopa district, Colorado, the Marysvale district,
Utah, and the Freeland-Lamartine district, Colorado. In the Cochetopa district, several major east-trending faults are joined by northeast-trending faults of lesser displacement that curve into the east-trending faults as if they were large-scale gash veins (map by R. C. Derzay and R. C. Malan, in Derzay, 1956, pl. 1). Uranium was deposited in sandstone of Jurassic age and granite of Precambrian age where the northeast-t'rending faults join the major faults (R. C. Malan, H. W. Ranspot, and R. G. Spengler, written commun., 1957).

The Marysvale district is within a large graben that forms the valley of the Sevier River in south-central Utah. The eastern margin of the graben is the Sevier fault that extends almost continuously from northern Arizona into central Utah. The western margin of the graben is formed by two large faults, one trending northwest and called the Tushar fault, and another trending northeast (fig. 60). The central mining area, which contains all the larger uranium-bearing veins of the Marysvale district, is in one of a series of intrusives of Tertiary age. These intrusives are localized where the Sevier fault bends northeastward and where the northwest-trending Tushar fault is supplanted by the northeast-trending Elsinore fault (Callaghan and Parker, 1961). Although no major faults have been recognized in the central mining area, many small faults, shear zones, and joints are exposed in mine workings. The faults and shear zones show normal, reverse, and transverse displacements. Dominant trends of the faults and shear zones are northeast and northwest; a less pronounced trend is to the north. The northwest set of faults and shear zones dips $40^{\circ}-60^{\circ} \mathrm{SW}$., whereas the other sets dip almost vertically. Several periods of movement are indicated by brecciation of wallrock and early vein minerals as well as by minor displacement of vein structures following deposition of late vein minerals. Uranium minerals are most common in the northeast-trending faults, less common in the northwesttrending faults, and rare or absent in the north-trending faults. The faults, shear zones, and joints probably are related genetically to the large-scale high-angle faults that bound the Sevier River valley (Willard and Callaghan, 1962; Walker and Osterwald, 1956, p. 124). The mineralized northeast-trending faults are linked tension fractures formed by movement along the largescale faults or between intermediate-scale faults formed in the graben and related to the large faults.

Some of the gold-, silver-, copper-, lead-, and zincbearing veins in the Freeland-Lamartine mining district of the Front Range also contain small amounts of uranium (Harrison and Wells, 1956). Most of the uranium in the district was deposited at the curved parts of the veins (fig. 61), where late solutions deposited 

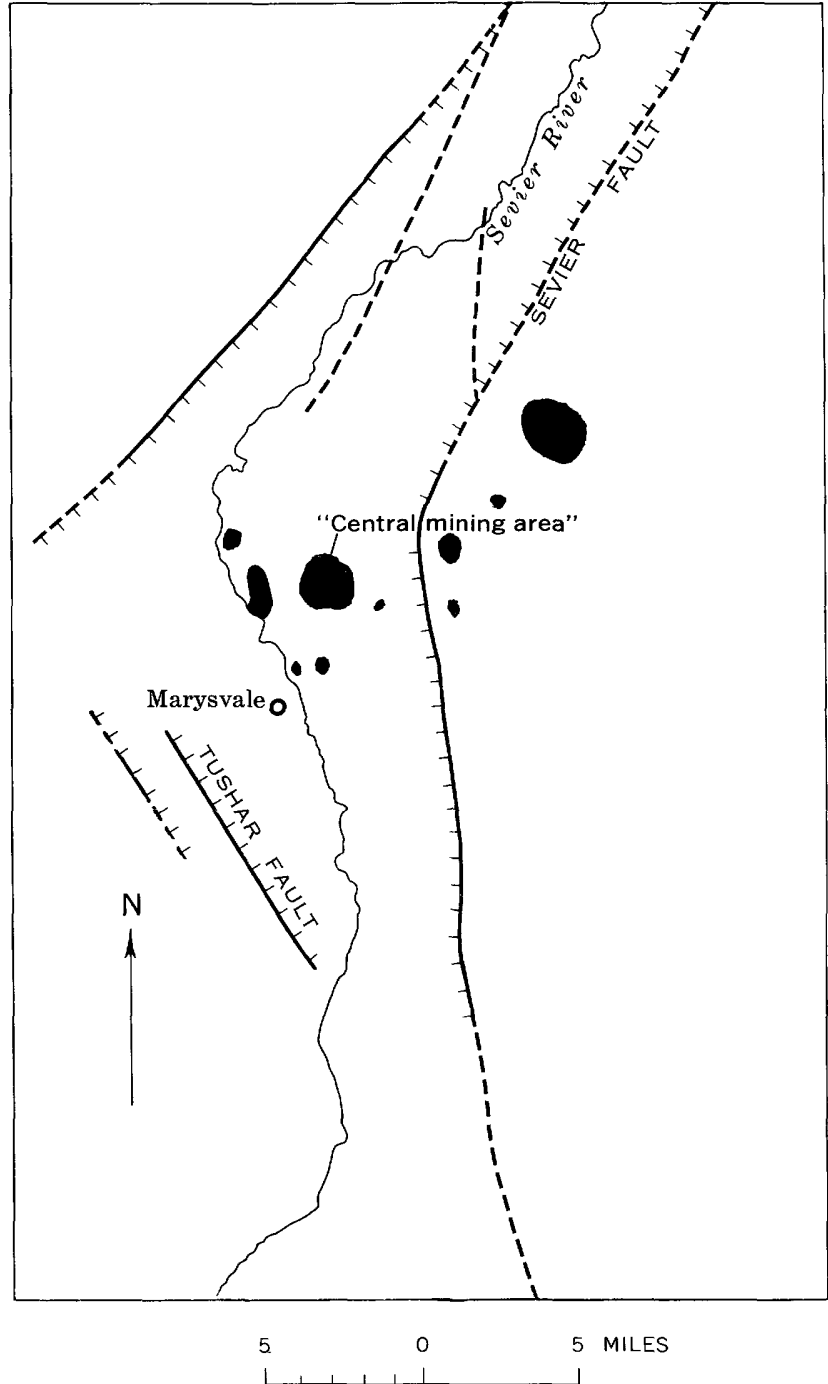

EXPLANATION

Intrusive rocks of Tertiary age

Fault

Dashed where inferred. Hachures, where

shown, indicate downthrown side

Figure 60.-Sketch map of Marysvale district, Piute County, Utah, showing relation of mining area to regional structure. After Kerr (1956, fig. 188).

chalcopyrite as well as pyrite-gold and galena-sphalerite mineral assemblages (Harrison and Wells, 1956, p. 80,86). Although no major faults are present as in the Cochetopa and Marysvale districts, the geometry of the veins suggested to Harrison and Wells (1956, p. 84 ) that the cymoidal veins resulted from regional shear (Lovering and Goddard, 1950, fig. 21; Harrison, 1955, p. 312-313). The shearing stress probably was absorbed by numerous small displacements along small faults, rather than along two major faults bordering the district (Harrison, 1955, p. 313).

\section{SUMMARY}

Various structural features that differ vastly in scale characterize uranium-bearing vein deposits and districts in the United States. Uranium is a widely dispersed element; hence, deposits of uranium occur in a wide variety of geologic environments. Any induced openings in rocks, whether produced by compressive, tensile, or torsional stresses, can provide a locale for uraniumbearing veins, if uranium is available within the region. Most such openings, however, probably result from local irregularities along the host structure, or from structural intersections, rather than from a particular type of district- or regional-stress pattern. No valid generalization can now be made that any one kind of structure is more favorable for uranium-bearing veins than any other kind, but most districts are characterized by structural patterns in which small- to intermediate-scale faults, joints, and folds were formed along large- to intermediate-scale faults, anticlines, and intrusive bodies, or between two intermediate- to largescale faults. These patterns include (1) en-echelon and parallel faults, folds, and joints flanking large-scale anticlinal uplifts, anticlines, or faults, (2) subparallel and en-echelon faults and fault zones in large crystalline-rock masses, (3) linked tension fractures between large-scale faults or shear zones, (4) faults subsidiary to parallel anticlines and synclines.

Structural controls for uranium-bearing vein deposits and districts, in general, are no different from structural controls for any other kind of metalliferousvein deposits and districts. Veins seem to occur along open faults and joints, in breccia, gouge, and mylonite in and near faults, and at intersections of faults and joints with other structural features or with porous rocks. Zones of faults and joints also seem to have localized some veins as well as other types of uranium deposits. The author does not entirely agree with Everhart (1956b, p. 102) that "Almost without exception, the vein deposits lie in districts where rocks have been subjected to tensional forces simultaneous or before mineral deposition." For example, the Ralston Creek and Golden Gate Canyon districts, Colorado, are in or near intermediate-scale high-angle reverse faults that result from local compressive forces (fig. 56). Many district structural patterns suggest large components of compressive stress, for example the Crooks Gap district, Wyoming (fig. 47). Some deposits within these districts were emplaced in brecciated brittle wallrocks 
as a result of local compression at bearing surfaces along irregular faults. In districts characterized by compressive-stress patterns, tensional stresses just before or during mineralization may have aided mineralization by opening preexisting breaks, but they probably were only local components and may have affected a distance of only a few inches. In many such districts, breaking characteristics of the host rocks were more important than orientation of stress components in the localization of deposits. Within individual veins, uranium minerals are localized at points where openings existed; many of these ore bodies are at points of locally reduced stress or of tensional stress. Available evidence indicates that uranium in most veins was deposited late in the sequence of events comprising the structural history of the encompassing area.

Structural features associated with uranium-bearing vein deposits are transitional to structural features associated with many disseminated impregnation and replacement (sandstone-type) uranium deposits. Transitional relations are shown by comparing individual veins with other types of deposits from various districts. Transitions are also shown by comparing deposits within districts containing both sandstone-type deposits and veins that are spatially and perhaps even genetically related to faults.

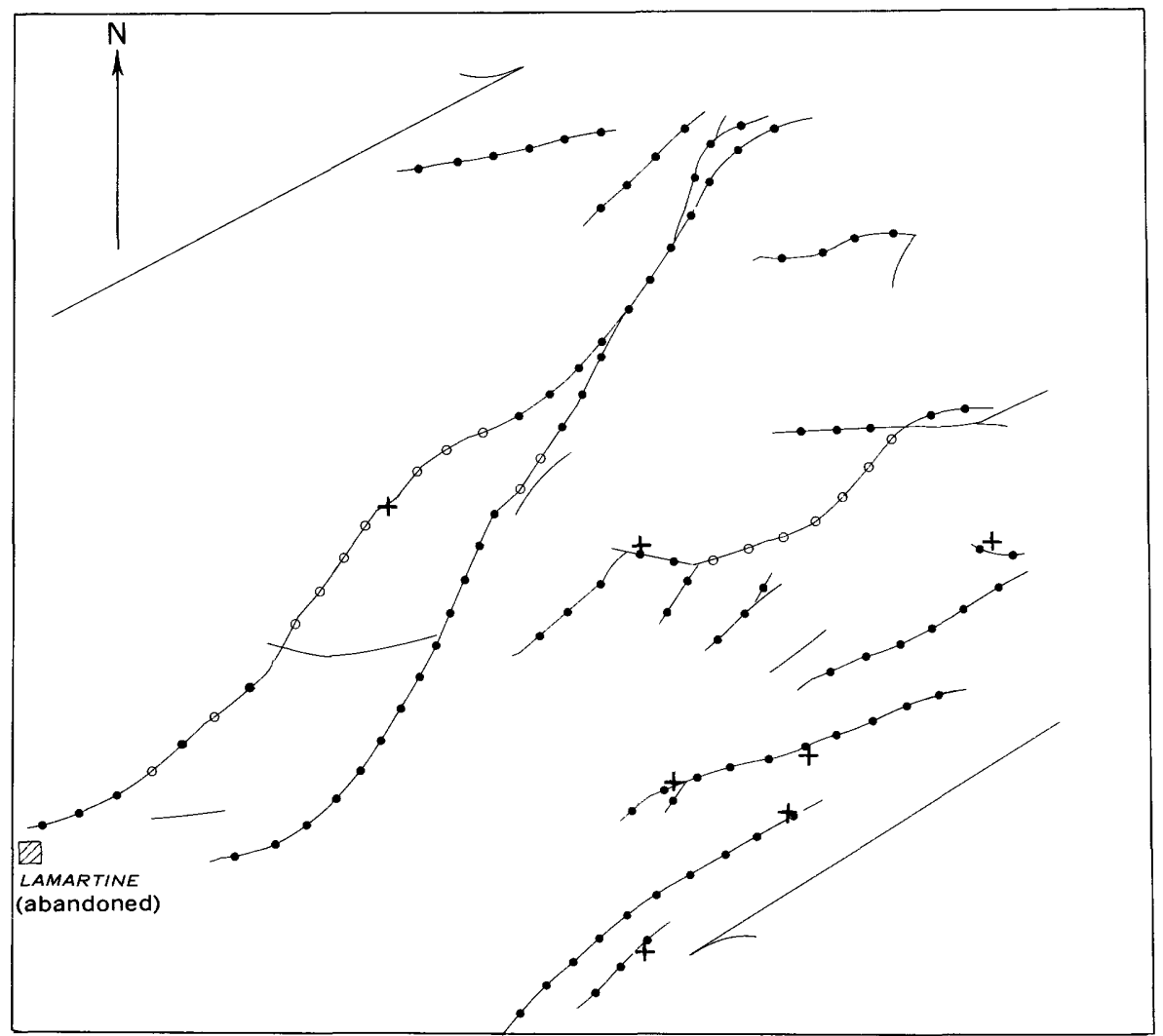

\section{EXPLANATION}

Trace of vein, type unknown

Trace of vein, galena-sphalerite type $-0-0$

Trace of vein, pyrite-gold type

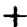

Uranium deposit, assays 0.01 percent uranium

FigURE 61.- Sketch map showing traces of major veins in part of the Freeland-Lamartine district, Clear Creek County, Colo., projected to 9,500 feet altitude. Arrows indicate directions of hypothetical regional shear. After Harrison and Wells (1956, fig. 8, pl. 5). 


\section{LITERATURE CITED}

Adams, J. W., and Stugard, Frederick, Jr., 1956, Wall-rock control of certain pitchblende deposits in Golden Gate Canyon, Jefferson County, Colorado: U.S. Geol. Survey Bull. 1030-G, p. 187-209.

Angelelli, V., 1956, Distribution and characteristics of the uranium deposits and occurrences in the Argentine Republic, in United Nations, Geology of uranium and thorium : Internat. Conf. Peaceful Uses Atomic Energy, Geneva, 1955, Proc., v. 6, p. 63-74.

Argall, G. O., Jr., 1954, Why Anaconda's uranium mines are unique: Mining World, v. 16, no. 10, p. 54-59.

Armstrong, F. C., 1957, Eastern and central Montana as a possible source area of uranium : Econ. Geology, v. 52, p. 211224.

Bain, G. W., 1950, Geology of the fissionable materials: Econ. Geology, v. 45, p. 273-323.

Becraft, G. E., 1956a, Turtle Lake quadrangle, Washington, in Geologic investigations of radioactive deposits-Semiannual progress report for June 1 to Nov. 30, 1956: U.S. Geol. Survey TEI-640, p. 146-150, issued by U.S. Atomic Energy Comm. Tech. Inf. Service, Oak Ridge, Tenn.

- 1956b, Uranium deposits of the Boulder Batholith, Montana, in Page, Stocking, and Smith, compilers: U.S. Geol. Survey Prof. Paper 300, p. 117-121.

Becraft, G. E., and Weis, P. L., 1957, Preliminary geologic map of part of the Turtle Lake quadrangle, Lincoln and Stevens Counties, Washington: U.S. Geol. Survey Mineral Inv. Field Studies Map MF-135.

Belluco, A., 1956, Uranium-bearing quartz veins of the "President Perón" deposit, Mendoza, in United Nations, Geology of uranium and thorium: Internat. Conf. Peaceful Uses Atomic Energy, Geneva, 1955, Proc., v. 6, p. 82-90.

Bergin, M. J., 1955, Maybell-Lay area, Moffat County, Colorado, in Geologic investigations of radioactive deposits-Semiannual progress report for June 1 to Nov. 30, 1955 : U.S. Geol. Survey TEI-590, p. 176-179, issued by U.S. Atomic Energy Comm. Tech. Inf. Service, Oak Ridge, Tenn.

Bergin, M. J., and Chisholm, W. A., 1956, Maybell-Lay area, Moffat County, Colorado, in Geologic investigations of radioactive deposits-Semiannual progress report for Dec. 1, 1955, to May 31, 1956 : U.S. Geol. Survey TEI-620, p. 190199, issued by U.S. Atomic Energy Comm. Tech. Inf. Service, Oak Ridge, Tenn.

Black, R. A., 1955, Gravity studies, in Geologic investigations of radioactive deposits-Semiannual progress report for June 1 to Nov. 30, 1955 : U.S. Geol. Survey TEI-590, p. 183-184, issued by U.S. Atomic Energy Comm. Tech. Inf. Service, Oak Ridge, Tenn.

Callaghan, Eugene, and Parker, R. L., 1961, Geology of the Monroe Quadrangle, Utah: U.S. Geol. Survey Geol. Quad. Map GQ-155.

Collins, G. E., 1930, Discussion, in Lovering, T. S., Localization of ore in the schists and gneisses of the mineral belt of the Front Range, Colorado: Colorado Sci. Soc. Proc., v. 12, p. 252-268.

Cook, F. S., and Wylie, E. T., 1956, The geology of the Woodrow mine, New Mexico : Econ. Geology, v. 51, p. 112-113.

Curtis, B. F., 1951, Summary of the Mesozoic stratigraphy of south-central Wyoming, in Wyoming Geol. Assoc. Guidebook 6th Ann. Field Conf., 1951 : p. 37-44.
Derzay, R. C., 1956, Geology of the Los Ochos uranium deposit, Saguache County, Colorado, in Page, Stocking, and Smith, compilers: U.S. Geol. Survey Prof. Paper 300, p. 137-141.

Drake, A. A., Jr., 1957, Geology of the Wood and East Calhoun mines, Central City district, Gilpin County, Colorado: U.S. Geol. Survey Bull. 1032-C, p. 129-170.

Everhart, D. L., 1956a, Tectonic control of uranium deposition in the Rocky Mountain region, in Rocky Mtn. Sec., Am. Assoc. Petroleum Geologists, 1956 Geological Record: Denver, Petroleum Information, p. 87-97.

1956b, Uranium-bearing vein deposits in the United States, in Page, Stocking, and Smith, compilers: U.S. Geol. Survey Prof. Paper 300, p. 97-103.

Gill, J. R., and Moore, G. W., 1955, Carnotite-bearing sandstone in Cedar Canyon, Slim Buttes, Harding County, South Dakota : U.S. Geol. Survey Bull. 1009-I, p. 249-264.

Goldstein, E. H., 1957, Geology of the Dakota formation uraninite deposite near Morrison, Colorado: Econ. Geology, v. 52, p. 775-785.

Granger, H. C., 1955, Dripping Spring quartzite, in Geologic investigations of radioactive deposits-Semiannual progress report for June 1 to Nov. 30, 1955: U.S. Geol. Survey TEI590, p. 187-191, issued by U.S. Atomic Energy Comm. Tech. Inf. Service, Oak Ridge, Tenn.

Granger, H. C., and Bauer, H. L., Jr., 1956, White Signal district, in Lovering, T. G., Radioactive deposits in New Mexico: U.S. Geol. Survey Bull. 1009-L, p. 329-349.

Hares, C. J., and others, 1946, Geologic map of the southern part of the Wind River Basin and adjacent areas in central Wyoming: U.S. Geol. Survey Oil and Gas Inv. Prelim. Map 60.

Harrison, J. E., 1953, Freeland-Lamartine district, in Search for and geology of radioactive deposits-Semiannual progress report for Dec. 1, 1952, to May 31, 1953 : U.S. Geol. Survey TEI-330, p. 96-97, issued by U.S. Atomic Energy Comm. Tech. Inf. Service, Oak Ridge, Tenn. 1955, Relation between fracture pattern and hypogene zoning in the Freeland-Lamartine district, Colorado: Econ. Geology, v. 50, p. 311-320.

Harrison, J. E., and Wells, J. D., 1956, Geology and ore deposits of the Freeland-Lamartine district, Clear Creek County, Colorado: U.S. Geol. Survey Bull. 1032-B, p. 33-127.

Hauptman, C. M., 1956, Uranium in the Pryor Mountain area of southern Montana and northern Wyoming: Uranium and Modern Mining, v. 3, no. 11, p. 14-21.

Hill, J. W., 1953, South-central districts, in Search for and geology of radioactive deposits-Semiannual progress report for Dec. 1, 1952, to May 31, 1953 : U.S. Geol. Survey TEI-330, p. 200-204, issued by U.S. Atomic Energy Comm. Tech. Inf. Service, Oak Ridge, Tenn.

Hinrichs, E. N., 1954, Moab-Inter-river area, Utah, strip-mapping, in Geologic investigations of radioactive depositsSemiannual progress report for June 1 to Nov. 30, 1954: U.S. Geol. Survey TEI-490, p. 35-36, issued by U.S. Atomic Energy Comm. Tech. Inf. Service, Oak Ridge, Tenn.

Hulin, C. D., 1929, Structural control of ore deposition: Econ. Geology, v. 24, p. 15-49.

Hunt, C. B., 1956, Cenozoic geology of the Colorado Plateau: U.S. Geol. Survey Prof. Paper 279, 99 p.

Kaiser, E. P., 1951, Uraniferous quartzite, Red Bluff prospect, Gila County, Arizona: U.S. Geol. Survey Circ. 137, 10 p. 
Kelley, v. C., 1955, Regional tectonics of the Colorado Plateau and relationship to the origin and distribution of uranium: New Mexico Univ. Pub. Geology, no. 5, 120 p.

Kerr, P. F., 1956, Rock alteration criteria in the search for uranium, in Page, Stocking, and Smith, compilers: U.S. Geol. Survey Prof. Paper 300, p. 633-639.

Kerr, P. F., Brophy, G. P., Dahl, H. M., Green, Jack, and Woolard, L. E., 1957, Marysvale, Utah, uranium area-geology, volcanic relations, and hydrothermal alteration: Geol. Soc. America Spec. Paper 64, 212 p.

Keys, W. S., and White, R. L., 1956, Investigation of the Temple Mountain collapse and associated features, San Rafael Swell, Emery County, Utah, in Page, Stocking, and Smith, compilers: U.S. Geol. Survey Prof. Paper 300, p. 285-298.

King, R. U., 1954, Colorado, in Geologic investigations of radioactive deposits-Semiannual progress report, Dec. 1, 1953, to May 31, 1954: U.S. Geol. Survey TEI-440, p. 173-175, issued by U.S. Atomic Energy Comm. Tech. Inf. Service, Oak Ridge, Tenn.

Koons, E. D., 1945, Geology of the Uinkaret plateau, northern Arizona : Geol. Soc. America Bull., v. 56, p. 151-180.

Kraus, Maximilian, 1915, Das staatliche Uran pecherzBergbaurevier bei St. Joachimsthal in Böhmen: Vienna, Bergbau und Hütte, v. 1, p. 3-30, 45-63, 93-112, 128-148, 168-183.

LeRoy, L. W., 1955, Summary of surface stratigraphy, in Rocky Mtn. Assoc. Geologists Field Conf. Guidebook, Geology of Front Range foothills west of Denver, Deer Creek to Ralston Creek, Jefferson County, Colorado: Denver, Petroleum Information, p. 15-24.

Lovejoy, E. M. P., 1954, Results of an aerial radiometric examination of the Ridenour Mine district, Hualapai Indian Reservation, Coconino County, Arizona, in Miller, R. D., Copper-uranium deposit at the Ridenour mine, Hualapai Indian Reservation, Coconino County, Arizona: U.S. Atomic Energy Comm. RME-2014, issued by Tech. Inf. Service, Oak Ridge, Tenn., p. 19-23.

Lovering, T. G., 1956, Radioactive deposits in New Mexico: U.S. Geol. Survey Bull. 1009-L, p. 315-390.

Lovering, T. S., 1942, Physical factors in the localization of ore, in Newhouse, W. H., ed., Ore deposits as related to structural features: Princeton, N. J., Princeton Univ. Press, p. 5-9.

Lovering, T. S., and Goddard, E. N., 1950, Geology and ore deposits of the Front Range, Colorado: U.S. Geol. Survey Prof. Paper 223, 319 p.

Maxwell, C. H., 1955, Bedrock geology of an area west of Denver, in Rocky Mtn. Assoc. Geologists Field Conf. Guidebook, Geology of Front Range foothills west of Denver, Deer Creek to Ralston Creek, Jefferson County, Colorado: Denver, Petroleum Information, plate 2.

Mencher, A. H., 1956, Why look? The dilemma of Mexican uranium: Uranium Mag., v. 3, no. 7, p. 10-14.

Miller, R. D., 1954, Copper-uranium deposit at the Ridenour mine, Hualapai Indian Reservation, Coconino County, Arizona : U.S. Atomic Energy Comm. RME-2014, p. 1-23, issued by Tech. Inf. Service, Oak Ridge, Tenn.

Moore, F. B., and Butler, C. R., 1952, Pitchblende deposits at the Wood and Calhoun mines, Central City mining district, Gilpin Gounty, Colorado: U.S. Geol. Survey Circ. 186, 8 p.

Moore, F. B., Cavender, W. S., and Kaiser, E. P., 1957, Geology and uranium deposits of the Caribou area, Boulder County, Colorado: U.S. Geol. Survey Bull. 1030-N, p. 517-552.
Newhouse, W. H., 1942, Structural features associated with the ore deposits described in this volume, in Newhouse, W. H., ed., Ore deposits as related to structural features : Princeton, N.J., Princeton Univ. Press, p. 9-53.

Norman, H. W., 1957, Uranium deposits of northeastern Washington: Mining Eng., v. 9, p. 662-666.

Osterwald, F. W., 1961, Critical review of some tectonic problems in Cordilleran foreland: Am. Assoc. Petroleum Geologists Bull., v. 45, p. 219-237.

Osterwald, F. W., and Dean, B. G., 1958a, Preliminary tectonic map of Wyoming east of the overthrust belt, showing the distribution of uranium deposits : U.S. Geol. Survey Mineral Inv. Field Studies Map MF-127.

1958b, Preliminary tectonic map of northern Colorado and northeastern Utah showing the distribution of uranium deposits : U.S. Geol. Survey Mineral Inv. Field Studies Map MF-130.

1961, Relation of uranium deposits to tectonic pattern of the Central Cordilleran foreland: U.S. Geol. Survey Bull. 1087-I, p. 337-390.

Page, L. R., Stocking, H. E., and Smith H. B., compilers, 1956, Contributions to the geology of uranium and thorium by the United States Geological Survey and Atomic Energy Commission for the United Nations International Conference on Peaceful Uses of Atomic Energy, Geneva, Switzerland, 1955 : U.S. Geol. Survey Prof. Paper 300, 739 p.

Reichert, S. O., 1954, Geology of the Golden-Green Mountain area, Jefferson County, Colorado: Colorado School Mines Quart., v. 49, no. 1, 96 p.

Ridland, G. C., 1950, Radioactivity at the Caribou silver mine, Boulder County, Colorado: Mining Eng., v. 187, p. 98-101.

Roberts, W. A., and Gude, A. J., 3d, 1953a, Uranium-bearing deposits west of Clancey, Jefferson County, Montana: U.S. Geol. Survey Bull. 988-F, p. 69-87.

1953b, Geology of the area adjacent to the Free Enterprise mine, Jefferson County, Montana: U.S. Geol. Survey Bull. 988-G, p. 143-155.

Sears, J. D., 1924, Relations of the Browns Park formation and the Bishop conglomerate, and their role in the origin of Green and Yampa Rivers: Geol. Soc. America Bull., v. 35, p. 279-304.

Sheridan, D. M., 1956, Ralston Buttes, Colorado, in Geologic investigations of radioactive deposits-Semiannual progress ,report for June 1 to Nov. 30, 1956 : U.S. Geol. Survey TEI640, p. 125-137, issued by U.S. Atomic Energy Comm. Tech. Inf. Service, Oak Ridge, Tenn.

Sheridan, D. M., Maxwell, C. H., Albee, A. L., and Van Horn, Richard, 1958, Preliminary map of bedrock geology of the Ralston Buttes quadrangle, Jefferson County, Colorado: U.S. Geol. Survey Mineral Inv. Field Studies Map MF-179.

Shoemaker, E. M., 1956, Structural features of the central Colorado Plateau and their relation to uranium deposits, in Page, Stocking, and Smith, compilers: U.S. Geol. Survey Prof. Paper 300, p. 155-170.

Sims, P. K., 1956, Paragenesis and structure of pitchblendebearing veins, Central City district, Gilpin County, Colorado: Econ. Geology, v. 51, p. 739-756.

Sims, P. K., Osterwald, F. W., and Tooker, E. W., 1955, Uranium deposits in the Eureka Gulch area, Central City district, Gilpin County, Colorado: U.S. Geol. Survey Bull. 1032-A, p. 1-31.

Staatz, M. H., and Osterwald, F. W., 1959, Geology of the Thomas Range fluorspar district, Juab County, Utah: U.S. Geol. Survey Bull. 1069, 97 p. 
Stephens, J. G., 1955, Crooks Gap area, Fremont County, Wyoming, in Geologic investigations of radioactive depositsSemiannual progress report for June 1 to Nov. 30, 1955: U.S. Geol. Survey TEI-590, p. 179-184, issued by U.S. Atomic Energy Comm. Tech. Inf. Service, Oak Ridge, Tenn.

1956, Crooks Gap area, Fremont County, Wyoming, in Geologic investigations of radioactive deposits - Semiannual progress report for Dec. 1, 1955, to May 31, 1956: U.S. Geol. Survey TEI-620, p. 200, issued by U.S. Atomic Energy Comm. Tech. Inf. Service, Oak Ridge, Tenn.

1964, Geology and uranium deposits at Crooks Gap, Fremont County, Wyoming: U.S. Geol. Survey Bull. 1147-F, 82 p.

Stewart, W. A., 1955, Structure of the foothills area west of Denver, Colorado, in Rocky Mtn. Assoc. Geologists Field Conf. Guidebook, Geology of Front Range foothills west of Denver, Deer Creek to Ralston Creek, Jefferson County, Colorado: p. 25-30. Denver, Petroleum Information.

Thaden, R. E., 1955, Grants area, New Mexico, in Geologic investigations of radioactive deposits-Semiannual progress report for June 1 to Nov. 30, 1955: U.S. Geol. Survey TEI590, p. 58-59, issued by U.S. Atomic Energy Comm. Tech. Inf. Service, Oak Ridge, Tenn.

Theobald, P. K., and Guilinger, R. R., 1955, A radioactive copperbearing shear zone in the vicinity of the F.M.D. mine, Jefferson County, Colorado, in Geologic investigations of radioactive deposits-Semiannual progress report for June 1 to Nov. 30, 1955 : U.S. Geol. Survey TEI-590, p. 202-212, issued by U.S. Atomic Energy Comm. Tech. Inf. Service, Oak Ridge, Tenn.

Theobald, P. K., and King, R. U., 1954, Colorado-Wyoming district, in Geologic investigations of radioactive depositsSemiannual progress report for June 1 to Nov. 30, 1954: U.S. Geol. Survey TEI-490, p. 223-230, issued by U.S. Atomic Energy Comm. Tech. Inf. Service, Oak Ridge, Tenn.

Thurlow, E. E., 1956, Uranium deposits at the contact of metamorphosed sedimentary rocks and granitic intrusive rocks in western United States, in Page, Stocking, and Smith, compilers: U.S. Geol. Survey Prof. Paper 300, p. 85-89.

Thurlow, E. E., and Reyner, M. L., 1950, Free Enterprise uranium prospect, Jefferson County, Montana: U.S. Atomic Energy Comm. RMO-678, 13 p., issued by Tech. Inf. Service, Oak Ridge, Tenn.
Thurlow, E. E., and Reyner, M. L., 1952, Preliminary report on uranium-bearing deposits of the northern Boulder batholith region, Jefferson County, Montana: U.S. Atomic Energy Comm. RMO-800, 62 p., issued by Tech. Inf. Service, Oak Ridge, Tenn.

Thurston, W. R., Staatz, M. H., Cox, D. C., and others, 1954, Fluorspar deposits of Utah: U. S. Geol. Survey Bull. 1005, $53 \mathrm{p}$.

Ussher, W. A. E., Barrow, G., and MacAlister, D. A., 1909, The geology of the country around Bodmin and St. Austell: Great Britain Geol. Survey sheet Mem. 347, 201 p.

Walker, G. W., and Osterwald, F. W., 1956, Relation of secondary uranium minerals to pitchblende-bearing veins at Marysvale, Piute County, Utah, in Page, Stocking, and Smith, compilers: U.S. Geol. Survey Prof. Paper 300, p. 123-129.

- 1963, Introduction to the geology of uranium-bearing veins in the conterminous United States, including sections on geographic distribution and classification of veins: U.S. Geol. Survey Prof. Paper 455-A, p. 1-28 [1964].

Weis, P. L., 1956, Stevens County, Washington, in Geologic investigations of radioactive deposits-Semiannual progress report for Dec. 1, 1955, to May 31, 1956 : U.S. Geol. Survey TEI-620, p. 222-223, issued by U.S. Atomic Energy Comm. Tech. Inf. Service, Oak Ridge, Tenn.

Willard, M. E., and Callaghan, Eugene, 1962, Geology of the Marysvale quadrangle, Utah: U. S. Geol. Survey Geol. Quad. Map GQ-154.

Wilmarth, V. R., Bauer, H. L., Jr., Staatz, M. H., and Wyant, D. G., 1952, Uranium in fluorite deposits, in Selected papers on uranium deposits in the United States: U.S. Geol. Survey Circ. 220, p. 13-18.

Wright, H. D., Bieler, B. H., Shulhof, W. P., and Emerson, D. O., 1954, Mineralogy of uranium-bearing deposits in the Boulder batholith, Montana: U.S. Atomic Energy Comm. RME-3095, 80 p., issued by Tech. Inf. Service, Oak Ridge, Tenn.

Wright, H. D., and Shulhof, W. P., 1957, Mineralogy of the Lone Eagle uranium-bearing mine in the Boulder batholith, Montana : Econ. Geology, v. 52, p. 115-131.

Zeller, H. D., 1957, The Gas Hills uranium district and some probable controls for ore deposition, in Wyoming Geol. Assoc. Guidebook, 12th Ann. Field Conf., Southwest Wind River Basin : p. 156-160.

Zeller, H. D., Soister, P. E., and Hyden, H. J., 1956, Preliminary geologic map of the Gas Hills uranium district, Fremont and Natrona Counties, Wyoming: U.S. Geol. Survey Mineral Inv. Field Studies Map MF-83. 
Geology of Uranium-Bearing

Veins in the Conterminous

United States

GEOLOGICAL SURVEY PROFESSIONAL PAPER 455

This professional paper was published

as chapters $A-F$ and $G$

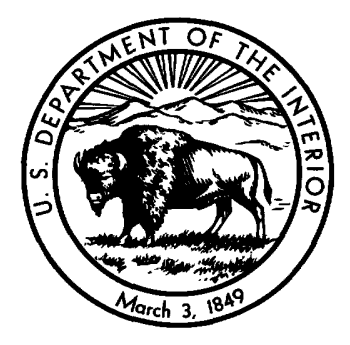


UNITED STATES DEPARTMENT OF THE INTERIOR

STEWART L. UDALL, Secretary

GEOLOGICAL SURVEY

Thomas B. Nolan, Director 


\section{CONTENTS}

[The letters in parentheses preceding the titles designate separately published chapters]

Page

(A) Introduction to the geology of uranium-bearing veins in the conterminous United States, including sections on geographic distribution and classification of veins, by George W. Walker and Frank W. Osterwald.

(B) Age of uranium-bearing veins in the conterminous United States, by George W. Walker.

(C) Host rocks and their alterations as related to uranium-bearing veins in the conterminous United States, by George W. Walker

(D) Mineralogy, internal structural and textural characteristies, and paragenesis of uranium-bearing veins in the conterminous United States, by George W. Walker and John W. Adams .

(E) Supergene alteration of uranium-bearing veins in the conterminous United States, by George W. Walker............-

(F) Concepts of origin of uranium-bearing veins in the conterminous United States, by George W. Walker and Frank. W. Osterwald . . .

(G) Structural control of uranium-bearing vein deposits and districts in the conterminous United States, by Frank W. Osterwald 
, 
